Ana Letícia Gori Lusa

\title{
Estudos bioquímicos e biofísicos de metaloproteases/desintegrinas de venenos de serpentes
}

Dissertação apresentada ao Instituto de Física de São Carlos, da Universidade de São Paulo, como parte dos requisitos para obtenção do título de Mestre em Ciências Física Aplicada.

Área de concentração: Física Biomolecular Orientadora: Profa. Dra. Dulce Helena Ferreira de Souza 


\section{AUTORIZO A REPRODUÇÃO E DIVULGAÇÃO TOTAL OU PARCIAL DESTE TRABALHO, POR QUALQUER MEIO CONVENCIONAL OU ELETRÔNICO, PARA FINS DE ESTUDO E PESQUISA, DESDE QUE CITADA A FONTE.}

Lusa, Ana Letícia Gori.

Estudos bioquímicos e biofísicos de metaloproteases/desintegrinas de venenos de serpentes /Ana Letícia Gori Lusa; orientador Dulce Helena Ferreira de Souza.-São Carlos, 2008.

$81 \mathrm{p}$.

Dissertação (Mestrado -Programa de Pós-Graduação em Ciências. Área de concentração: Física Aplicada: opção Física Biomolecular) - Instituto de Física de São Carlos da Universidade de São Paulo.

1. Metaloprotease. 2.Desintegrina. 3.Autólise. 4.Dicroísmo circular. 5.Fluorescência. I. Título. 
Folha de aprovação 
Dedico aos meus pais, Jaime e Pascoala, e ao meu irmão que sempre estiveram do meu lado e com qual eu sempre pude contar. 


\section{Agradecimentos}

Á Deus pelo dom da vida.

Aos meus pais e ao meu irmão, que além do apoio incondicional, me deram lições que me ajudaram a enfrentar vários desafios.

Aos meus avós, que mesmo ausentes, foram exemplos de vida.

Aos meus tios e primos que sempre estiveram do meu lado.

Ao Douglas pelo "ombro" que tive quando mais precisei.

A Prof. Dra. Dulce Helena Ferreira de Souza, pela orientação, amizade, paciência e ajuda nos momentos mais difíceis desse projeto.

A Profa. Heloisa Araújo pelas dicas e pelas ajudas de material, quando precisei.

Ao Prof. Dr. Richard Charles Garratt pela ajuda que tive no começo do curso.

Ao Dr. Wanius Garcia pela ajuda nesse trabalho.

Aos meus amigos que ajudaram diretamente: João Renato, Dani Chiarelli, Alexandre, Lívia Manzine, Carol Figueira, Amanda, Alessandro, Lílian (Barbie), Dani Trivela, Carol Hoff. 
Aos amigos, que mesmo indiretamente, ajudaram muito: Maria, Carol Guzzi, Matheus, Elizandra, Mamé, Fernanda, Napo, Caqui, Jaque, Marta, Nico, Renata, Lívia Salum, Lucas, Natalia, Aline, Kelvin, Vitor(B2), Nádia, Tavinho, Sandra K., Fernando B., Karime, Claudia A., Mirela, Leonardo, Mario.

As técnicas Susana e Bianca do laboratório de Bioquímica e Andressa e Bel do laboratório de Biofísica.

As pessoas que me ajudaram muito na Federal: Carmem, Mônica, Débora, Márcia Cominetti, Milena, Nabor.

As minhas amigas de "sempre": Cristiane, Thaiza, Marcela, Tais, Tatiane, Polyanna, Mariana, Meme, Kelly, Carol, Carla, Bia.

Aos funcionários do Instituto de Física de São Carlos. Em especial, o pessoal da secretaria de Pós-Graduação.

Aos funcionários da CBME.

A CNPQ pelo apoio financeiro.

$\mathrm{E}$ a todos aqueles que ajudaram diretamente e indiretamente e minha memória não foi capaz de lembrar.

MUITO OBRIGADA, ESSE TRABALHO TAMBÉM É DE VOCÊS. 
“Já de saída minha vida entortou, mas vou até o fim...”(Chico Buarque) 



\section{Resumo}

Metaloproteases/desintegrinas (MD) isoladas de venenos de serpentes são potentes inibidores de agregação plaquetária e de adesão celular, processos envolvidos em doenças como trombose e câncer. As MD pertencem a classe PIII das SVMPs ('snake venom metalloproteinases') que são constituídas por três domínios: metaloprotease (M), tipo-desintegrina (D) e rico em cisteína (C). A função dos três domínios nas atividades das moléculas ainda não é totalmente conhecida, e estudos com o objetivo de esclarecer suas funções são importantes para o desenvolvimento de novos fármacos. Algumas proteínas da classe PIII apresentam elevada atividade auto-proteolítica (liberando peptídeo constituído dos domínios D e C) enquanto que em outras PIII esta atividade não é menos evidente. Neste trabalho nós estudamos MD isoladas de veneno de Bothrops jararaca (bothropasina) e Bothrops alternatus (alternagina) em relação aos seus processos de autólise. Alternagina e bothropasina apresentaram diferentes comportamentos em relação à autoproteólise, apesar do elevado grau de identidade entre as duas moléculas. Nesse trabalho, caracterizamos a estabilidade química e o comportamento de desenovelamento da proteína alternagina nativa pela guanídina $\mathrm{HCl}$ usando emissão de fluorescência intrínseca em combinação com espectroscopia de dicroísmo circular ' far' $^{\prime}$ UV. As amostras de alternagina, purificadas do veneno liofilizado, foram monitoradas por dicroísmo em comprimento de onda de $220 \mathrm{~nm}$ e os resultados mostraram estruturas intermediárias no processo de desnaturação da proteína. Estudos semelhantes foram feitos com a bothropasina, com o objetivo de relacionar seus diferentes comportamentos auto-proteolíticos com os processos de desnaturação. Nas duas proteínas ocorreu uma alta correlação entre os estudos de auto-proteolise e de desnaturação.

As MD isoladas de B. jararaca, jararagina e bothropasina, são isoformas descritas na literatura como isoláveis através de diferentes cromatografias. Neste trabalho, utilizamos os diferentes protocolos descritos para verificar a porção da isoforma majoritária no veneno. As amostras de proteína serão analisadas por espectrometria de massas, uma vez que a região $\mathrm{N}$-terminal das proteínas está bloqueada.

Palavra-chave: Metaloprotease, Desintegrina, Autólise, Dicroísmo circular, Fluorescência. 


\begin{abstract}
Metalloproteinases/disintegrin (MD) isolated from snake venom are potent inhibitors of platelet aggregation and cell adhesion, processes involved in illnesses as cancer and thrombosis. MD belong to the PIII class of the metalloproteinase/disintegrin gene family and they are constituted by three domains: the catalytic domain, metalloprotease; disintegrin-like (D) and cysteine-rich (R). Some MD proteins are rapidly processed (producing the disintegrin-like/ cysteine-rich domains), while others MD are processed slowly. In this work, we studied the autolysis process of the MD isolated from the venom of Bothrops jararaca (bothropasin) and Bothrops alternatus (alternagin). Despite high sequence identity, alternagin and bothropasin showed different autolysis processes. The processing of the alternagin produces an intermediate with molecular mass of $43 \mathrm{kDa}$ whereas in the processing of the bothropasin this intermediate is almost not observable.

In this work we studied alternagin and bothropasin under the viewpoint of chemical stability and the unfolding process to guanidine hydrochloride $(\mathrm{Gnd}-\mathrm{HCl})$ using dichroism circular and fluorescence spectrometry. The CD spectra $(220 \mathrm{~nm})$ of the alternagin purified from the lyophilized venom showed an intermediate structure in the unfolding process. These studies were performed on bothropasin with the goal to relate the autolysis and unfolding process. These studies revealed a high correlation between both proteins .

The MD isolated from B. jararaca, jararagin and bothropasin, are isophorms purified from different chromatograph processes reported in the literature. In this work, different purification processes were used to check the major isophorm. Due to the blocked N-terminal region, these proteins will be assessed by mass spectrometry.
\end{abstract}

Key-words: Metalloprotease, Disintegrin, Autolysis, Dichroism circular, Fluorescence. 


\section{Lista de Figuras}

Figura 1.1 Interação entre desintegrina (fertilina) e a integrina $\alpha_{3} \beta_{1}$ durante a fusão do espermatozóide com o óvulo

Figura 1.2 Diagrama esquemático das estruturas das classes das metaloproteases de veneno de serpente (SVMPs)

Figura 1.3 Estrutura da bothropasina complexada com o inibidor POL647Alinhamento entre as seqüências da jararagina e bothropasina

Figura 1.4

Alinhamento entre as seqüências da jararagina e bothropasina

30

30

Figura 4.1 Análise do processo de purificação da bothropasina pelo método de Mandelbaum e colaboradores

Figura 4.2 Análise do processo de purificação da bothropasina pelo método de Muniz

Figura 4.3 Análise do processo de purificação da jararagina, segundo o método de Paine e colaboradores

Figura 4.4 Análise da primeira etapa da purificação da alternagina, partindo de 50 mg de veneno de B. alternatus em tampão $10 \mathrm{mM}$ de fosfato de sódio $\mathrm{pH}$ 7,2 .

Figura 4.5 Segunda etapa da purificação da alternagina, amostras que foram eluídas com tampão de 0,3M de $\mathrm{NaCl}$ na ANX Fast Flow

Figura 4.6 Segunda etapa do processo de purificação da bothropasina pelo método de Muniz

Figura 4.7 Análise em SDS-PAGE da autólise da alternagina a $25^{\circ} \mathrm{C}$.

Figura 4.8 Análise em SDS-PAGE da autólise da alternagina a $25^{\circ} \mathrm{C}$.

Seqüência de aminoácidos da bothropasina

51

55

Figura 4.10

Análise comparativa do processo de autólise das MDs de B.jararaca

55

Figura 4.11

Figura 4.12 Análise em SDS-PAGE da autólise da alternagina em temperatura de $6^{\circ} \mathrm{C}$ Análise em SDS-PAGE da autólise da bothropasina em temperatura de $6^{\circ} \mathrm{C}$

Figura 4.13 Análise dos produtos da autólise das metaloproteianses/desintegrinas por imunoblotting.

Figura 4.14 Curva de desnaturação química por hidrocloreto de guanidina (Gnd-HCl), monitoradas por dicroísmo circular, das proteínas bothropasina e a alternagina, em comprimento de onda de $220 \mathrm{~nm}$.

Figura 4.15 Curva de desnaturação química por hidrocloreto de guanidina, monitoradas por dicroísmo circular, em comprimento de onda $220 \mathrm{~nm}$, das proteínas alternagina e a alt-C

Figura 4.16 Curva de desnaturação química por hidrocloreto de guanidina, monitoradas por dicroísmo circular, em comprimento de onda $220 \mathrm{~nm}$, das proteínas bothropasina e a bot-C:

Figura 4.17 Espectro do dicroísmo circular, de elipcidade em função do comprimento de onda, das proteínas: alternagina e alt-C 
Figura 4.18 Espectros de fluorescência, com excitação a 280nm, em diferentes concentrações de agente desnaturantes, hidrocloreto de guanidina, das proteínas

Figura 4.19 Espectros de fluorescência, com excitação a 295nm, em diferentes concentrações de agente desnaturantes, hidrocloreto de guanidina, das proteínas

Figura 4.20 Comparação entre as emissões de fluorescência com excitação em 280nm e $295 \mathrm{~nm}$ da alternagina.

Figura 4.21 Comparação entre curvas de desnaturação medidas por fluorescência (excitação 66 a $280 \mathrm{~nm}$ e $295 \mathrm{~nm}$ ) e por dicroísmo circular da alternagina

Figura 4.22 Curvas de desnaturação, monitoradas pela fluorescência, da alternagina e 66 bothropasina em diferentes concentrações de $\mathrm{Gnd}-\mathrm{HCl}$ com excitação em $280 \mathrm{~nm}$ (a) e a $295 \mathrm{~nm}$ (b). 


\section{Lista de Tabelas}

Tabela 1.1 Combinações de subunidades alfa $(\alpha)$ e beta $(\beta)$ de integrinas e seus ligantes 
Abreviaturas

ADAMs - a disintegrin-like and metalloprotease domain

ALT-C - Alternagina-C

BSA - soroalbumina bovina

cDNAs - Complementary DNA

CD - circular dichroism

CI/VM - aminoácidos: cisteína, isoleucina/ valina, metionina

DC - desintegrina e rico em cisteína

D/ECD - aminoácidos: aspartato/glutamato, cisteína, aspartato

EGF - fator de crescimento epidermal

ERK - quinase extracelular regulada

FAK - quinase de adesão focal

Gnd - guanidina

HPLC - High Perfomance liquid cromatoghaphy

Lcp - circularmente polarizada para esquerda

M/D- Metaloprotease/Desintegrina

MDCs - metalloprotease/desintegrin /cystein domain

MMPs - Mammals metaloproteases

PDGF - Fator de crescimento derivado de plaqueta

PI3-kinase - fosfatidilinositol 3-kinase

PM- peso molecular

RGD- aminoácidos: arginina, glicina, aspartato

$\mathrm{Rcp}$ - circularmente polarizada para direita

SDS - dodecil sulfato de sódio

SDS-PAGE- Sodium Duodecyl Sulfate - Polyacrilamide Gel Electrophoresis

SVMPs - snake venom metaloprotease

TACE - Tumor necrosis factor alpha converting enzyme

TGF- $\beta$ - Fator de crescimento transformante do tipo beta

TNF- $\alpha$ - Tumor necrosis factor $\alpha$

VEGF - vascular endothelial growth factor 


\section{Sumário}

Capítulo 1- Introdução

1.1- Integrinas e Desintegrinas

1.2-Metaloproteases

1.3-Jararagina e Bothropasina

1.4-Alternagina

Capítulo 2- Objetivos

3.1-Purificação das proteínas

3.1.1-Purificação da alternagina

3.3- Preparação das amostras para espectrometria de massa.

3.4-Autólise da alternagina e da bothropasina

3.5-Medidas de dicroísmo circular

3.7- Medidas fluorimétricas

Capítulo 4-Resultados e discussão

4.1-Estudos de Isolamento de metaloproteases/desintegrinas (MD) de veneno de $B$.

jararaca.

4.2-Estudo comparativo dos processos de autólise de metaloproteases

/desintegrinas (MDs)

4.3-Estudos do desenovelamento da alternagina e da bothropasina através das técnicas de Dicroísmo Circular e Fluorescência 
Capítulo 5- Conclusões

Capítulo 6 - Referências 


\section{Capítulo 1 - Introdução}

A investigação científica tem enfocado o estudo dos venenos de serpentes, seu isolamento e a caracterização de seus componentes. Os venenos viperídicos são compostos de misturas complexas de centenas de moléculas ativas farmacologicamente, incluindo componentes orgânicos e minerais (histamina e outros alergênicos, poliaminas, alcalóides), peptídeos pequenos e proteínas (MARKLAND, 1998; FRY, 1999; MÉNEZ, 2002).

Um dos sistemas mais suscetíveis aos venenos viperídicos é o vascular, porque nesses venenos são encontradas metalo e serinoproteases de complexa variação na especificidade pelo substrato. Estas proteínas recebem a classificação de proteases, podendo agir de diferentes formas, com propriedades procoagulantes (SELISTRE; GIGLIO, 1987), hemorrágicas (SELISTRE et al., 1990; JOHNSON; OWNBY, 1993; MARSH, 1994), anticoagulantes (SELISTRE et al., 1990), fibrinolíticas (GUAN et al., 1991), ativadoras de plaquetas (SERRANO et al.,1995) e inibidora de agregação plaquetária ( KINI; EVANS, 1991; FUJIMURA et al., 1995). Além disso, os venenos de serpentes apresentam outros efeitos patológicos nas funções vitais, incluindo aqueles no sistema cardiovascular, função renal e sistema complemento (OUYANG et al., 1992, ESTEVÃO-COSTA, 2000).

Picadas de serpentes de membros do gênero Bothrops representam um importante problema de saúde estando envolvidos com $90 \%$ dos acidentes humanos com picadas de serpentes na América do Sul. O veneno deste gênero possui ações proteolítica, procoagulante e hemorrágica, sendo os distúrbios hemostáticos e os sinais locais como edema, hemorragia e necrose as principais manifestações clínicas observadas (MARUYAMA et al., 1990; SANCHEZ et al., 1992). O processo inflamatório causado pelas moléculas proteolíticas do veneno caracteriza-se clinicamente por edema e dor na região da picada. A necrose, manifestação local 
mais importante, limita-se ao tecido subcutâneo, mas pode comprometer estruturas mais profundas, como tendões, músculos e ossos, podendo causar distrofias e deixar seqüelas (LOMONTE et al., 1990; SELISTRE et al., 1990). Hemorragias sistêmicas e locais são complicações que comumente acontecem em acidentes com venenos de Bothrops, por suas toxinas procoagulantes. A ação das hemorraginas (metaloproteases) sobre a parede dos vasos contribui potencialmente para essas hemorragias (KAMIGUTI et al., 1996).

O único tratamento disponível para os acidentes causados por Bothrops consiste na administração do soro poliespecífico (MINISTÉRIO DA SAÚDE, 2003). A quantidade de antiveneno administrada ao paciente varia conforme a gravidade do caso, que é classificado em leve, moderado e grave, de acordo com as manifestações clínicas (CARDOSO et al., 1993). Este tratamento neutraliza eficientemente os efeitos sistêmicos observados, porém pouca neutralização é observada sobre os efeitos locais (GUTÍERREZ et al., 1981), devido ao rápido desenvolvimento da lesão.

\section{1-Integrinas e Desintegrinas}

As integrinas são glicoproteínas essenciais para a ligação entre o citoesqueleto de uma célula e a matriz extracelular e são expressas na superfície da célula (HYNES, 1992). As integrinas estão presentes em diversos organismos desde mamíferos, aves e até existem estudos em Drosophila. Estas são definidas como moléculas de adesão celular $\mathrm{Ca}^{+}$-dependentes (WOLPERT, 2000). A adesão celular é importante para determinação da forma da célula, na manutenção da função adequada e integridade dos tecidos.

Estruturalmente, as integrinas são proteínas heterodiméricas formadas por duas subunidades, $\alpha$ e $\beta$, associadas não covalentemente e codificadas por diferentes genes 
(WOLPERT, 2000; HYNES, 1987). De acordo com a similaridade seqüencial, o sistema de nomenclatura proposto para as integrinas categoriza as subunidades de cada heterodímero como $\alpha$ (120 a $180 \mathrm{kDa})$ e $\beta(90$ a $110 \mathrm{kDa})$, ambas do tipo transmembrânicas, cujas combinações definem as propriedades adesivas e de sinalização.

A maior parte da molécula de integrina está exposta ao meio extracelular, enquanto que o citoesqueleto de actina e o maquinário de sinalização estão associados a um pequeno domínio citoplasmático (DZAMBA et al., 2001). Existem cerca de 22 heterodímeros de integrinas constituídos de 17 formas de subunidades $\alpha$ e 8 formas da subunidade $\beta$ (PENTIKAINEN et al., 1999) e elas podem combinar-se para formar proteínas com diversas especificidades ligantes e atividades biológicas (PETRUZELLI et al., 1999). Na Tabela 1-1 encontram-se algumas dessas subfamílias e seus ligantes. 
Tabela 1-1- Combinações de subunidades alfa $(\alpha)$ e beta $(\beta)$ de integrinas e seus ligantes.(PETRUZZELLI et al., 1999)

\begin{tabular}{|c|c|c|}
\hline Subunidades & & Ligantes \\
\hline \multirow[t]{6}{*}{ Beta 1} & Alfa 1 & Colágeno, laminina \\
\hline & Alfa 2 & Colágeno, laminina \\
\hline & Alfa 3 & Colágeno, laminina, fibronectina \\
\hline & Alfa 4 & Fibronectina, molécula 1 de adesão celular vascular \\
\hline & AlfaV & Fibronectina \\
\hline & Alfa $6^{\mathrm{a}}, 6 \mathrm{~B}, 7$ & Laminina \\
\hline \multirow[t]{3}{*}{ Beta 2} & Alfa L & Molécula de adesão intercelular 1-2 \\
\hline & Alfa M & Componentes de complemento $\mathrm{C} 3 \mathrm{~b}$ \\
\hline & Alfa X & Fibrinogênio, Componentes de complemento C3b \\
\hline \multirow[t]{2}{*}{ Beta 3} & Alfa 11b & Fibrinogênio, fibronectina, fator de von Willebrand \\
\hline & Alfa V & Vitronectina, fibronectina \\
\hline Beta 4 & Alfa $6^{\mathrm{a}}, 6 \mathrm{~B}$ & Laminina, Kalanina \\
\hline Beta 5 & Alfa V & Vitronectina \\
\hline Beta 6 & Alfa $\mathrm{V}$ & Vitronectina \\
\hline \multirow[t]{2}{*}{ Beta 7} & Alfa 4 & Fibronectina \\
\hline & Alfa E & Caderina \\
\hline Beta 8 & $\mathrm{AlfaV}$ & Vitronectina \\
\hline
\end{tabular}

Quase toda célula expressa uma ou várias integrinas. O domínio citoplasmático das integrinas $\beta$ está ligado aos filamentos de actina através de proteínas de ligação (talina, vinculina e actinina $\alpha$ ) (WOLPERT, 2000).

Em muitas culturas de células, a adesão mediada por integrinas ocorre em locais específicos de adesão, os chamados contatos focais. Nesses locais, proteínas estruturais e de sinalização tais como as integrinas, proteínas de citoesqueleto e quinases se mostraram concentradas nesses sítios (LAFLAMME et al., 1996). A agregação de receptores e fosforilação da tirosina das integrinas, mediada pela quinase, são eventos chaves que resultam em diversos 
processos como a migração e diferenciação celular, remodelagem de tecidos, proliferação celular, angiogênese, invasão celular tumoral e metástase (HYNES, 1992; JULIANO, 1993).

Foi evidenciado que durante a progressão tumoral há uma alteração no padrão de expressão da integrina $\alpha_{3} \beta_{1}$, caracterizada por um aumento da expressão em melanomas metastáticos e em células metastáticas de carcinoma mamário (MORINI et al., 2000). Também foi encontrada uma correlação entre a presença desta integrina e da integrina $\alpha_{2} \beta_{1}$, além da habilidade de diferentes tipos de células tumorais aderirem ao osso cortical para metastatizá-lo (LUNDSTRÖM et al., 1998).

Estudos demonstram que durante a cicatrização de ferimentos a expressão da integrina $\alpha_{1} \beta_{1}$ em fibroblastos é diminuída, enquanto que a expressão da integrina $\alpha_{2} \beta_{1}$ apresenta-se sensivelmente aumentada (HENO, 2000). Isto ocorre devido à ação de fatores de crescimento tais como o TGF- $\beta$ (Fator de crescimento transformante do tipo beta) e PDGF (Fator de crescimento derivado de plaqueta). A integrina $\alpha_{2} \beta_{1}$ estaria relacionada com a cicatrização e formação de fibrose tecidual, juntamente com o colágeno. Sua função também estaria envolvida no recrutamento de leucócitos polimorfonucleares para o local de inflamação através da ligação com o colágeno. A comprovação foi obtida através de experimentos onde a locomoção de leucócito polimorfonuclear pôde ser inibida in vitro e in vivo pelo bloqueio desta integrina com anticorpo anti-subunidade- $\alpha_{2}$ (WERR et al., 2000). Outro fato que confirmou este resultado foi o de que esta integrina não foi detectada na superfície de leucócitos polimorfonucleares circulantes no sangue, sendo somente detectada quando estes extravasavam para dentro da pele ou cavidade peritoneal (WERR et al., 2000). Ivana e Heno (IVANA; HENO, 2000) também mostraram que a regulação da produção de MMPs (Mammal metaloproteases) pelas integrinas é muito importante na migração celular, na cicatrização tecidual e na invasão dos tecidos por células tumorais. 
Integrinas $\alpha_{11 b} \beta_{3}$ ligam-se a fibrinogênio na superfície das plaquetas, mediando a agregação plaquetária. Integrina $\alpha_{V} \beta_{3}$ é predominantemente expressa em células endoteliais e desempenha um importante papel na angiogênese. Integrina $\alpha_{5} \beta_{1}$ é bem distribuída em uma variedade de células; desempenha um papel crítico na adesão à matriz extracelular, bem como na formação de tecidos e órgãos durante o desenvolvimento embrionário (CLARK, 1996).

A maioria das integrinas reconhece a seqüência tripeptídica arginina-glicina-ácido aspártico (RGD) nos ligantes tais como colágeno, laminina, fibronectina, fibrinogênio, fator de von Willebrand, vitronectina (RUOSLAHTI, 1987). Assim, essa seqüência é reconhecida por muitas integrinas como sítio de adesão, apesar de outras seqüências também funcionarem como sítios de reconhecimento celular nessas proteínas de alto peso (GRAF et al., 1987; TASHIRO et al., 1989; KLOCZEWIAK et al., 1984).

A ligação reversível célula-matriz extracelular mediada pela integrina pode ser interrompida por pequenos peptídeos chamados "desintegrinas". Estes pequenos peptídeos contêm um domínio RGD que se liga às integrinas e competitivamente evitam a ligação mediada por integrina, das células com a laminina, a fibronectina e outras proteínas da matriz extracelular. Desintegrinas, por exemplo, participam da fusão dos gametas feminino e masculino durante a fertilização (Fig. 1-1) e fusão dos mioblastos durante o desenvolvimento muscular (WOLPERT, 2000). 


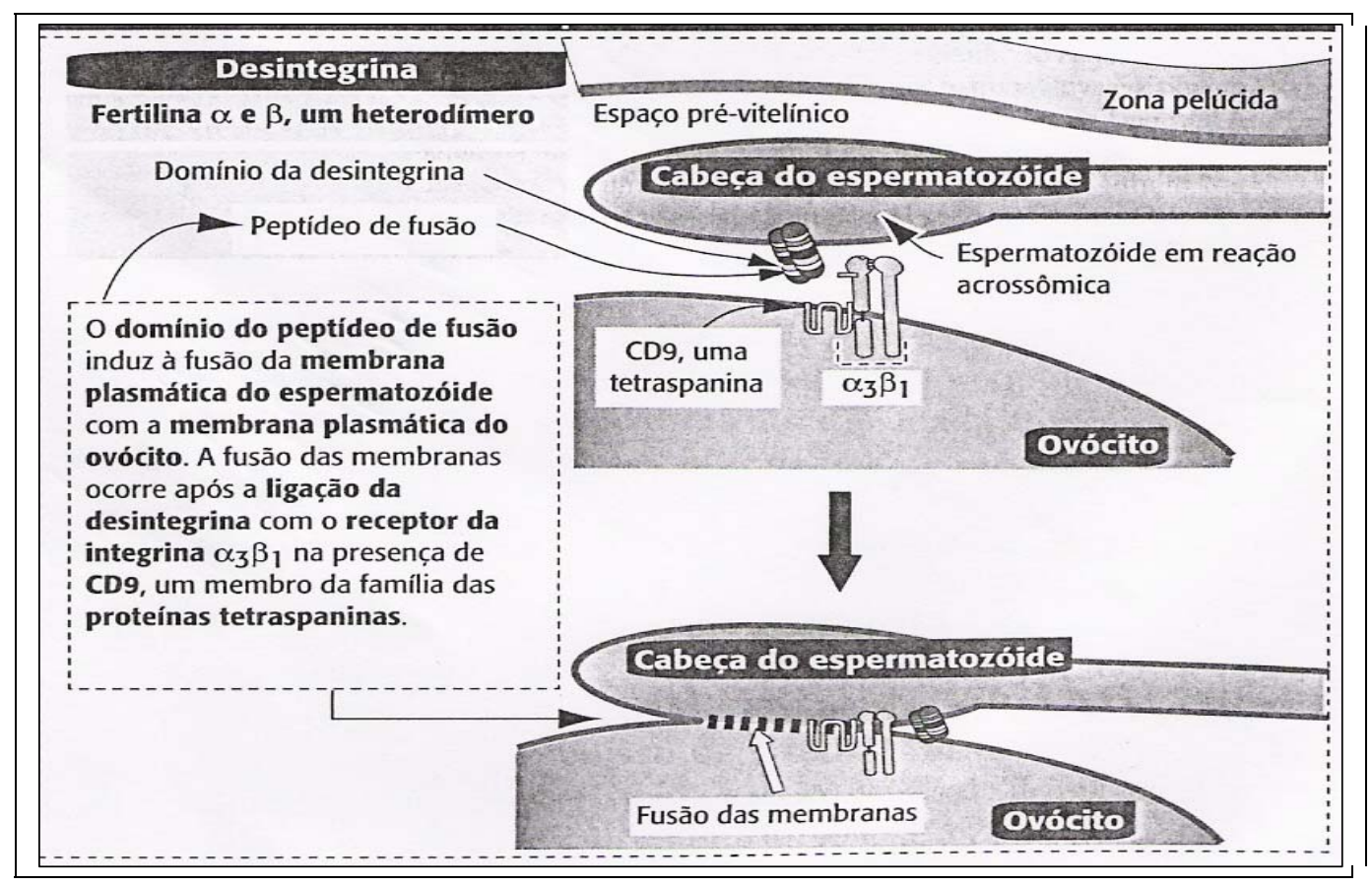

Figura 1-1 - Interação entre desintegrina (fertilina) e a integrina $\alpha 3 \beta 1$ durante a fusão do espermatozóide com o óvulo (WOLPERT, 2000).

O termo desintegrina foi usado pela primeira vez em 1989 para descrever um grupo de peptídeos de baixo peso molecular (5 a $9 \mathrm{kDa}$ ), ricos em cisteínas, derivado de venenos de serpentes, que interagem com integrinas na superfície da célula (DENNIS et al., 1989; GOULD et al., 1990; NIEWIAROWSKI et al., 1994). Foi proposto que as desintegrinas resultam do processamento proteolítico dos precursores homólogos a metaloproteases de venenos de serpentes ('snake venom metaloprotease'-SVMPs) de classe PII, compostos pelos domínios pré, pró, metaloprotease e desintegrina (BJARNASON; FOX, 1994; AU et al., 1991). Muitas desintegrinas são potentes inibidores de agregação plaquetária por agir como antagonista da ligação do fibrinogênio à plaqueta $\alpha_{\mathrm{IIb}} \beta_{3}$ (receptor integrina) devido ao motivo RGD em sua seqüência de aminoácidos (HUANG et al., 1987, MARUYAMA et al., 1997). Desintegrinas RGD são também potentes inibidores de adesão celular dependentes de integrinas e diversos trabalhos têm demonstrado resultados animadores na inibição do desenvolvimento de metástases, 
sugerindo que estas moléculas possam ser de grande valor na terapia do câncer (BEVIGLIA et al., 1995; DANEN et al., 1998). Resultados semelhantes foram obtidos com relação à prevenção de trombose em experimentos in vivo (SHEU; HUANG, 1994; SHEU et al., 1995). O estudo estrutural de diferentes desintegrinas tem fornecido resultados importantes na elucidação do mecanismo de ação destas proteínas e na especificidade com relação aos diferentes tipos de integrinas (SAUDEK et al., 1991).

Desta forma, as desintegrinas de venenos de serpentes apresentam um enorme potencial para estudos básicos de reconhecimento celular em malignidade e trombose, bem como potencial terapêutico (SHEU; HUANG, 1994; SHEU et al., 1994; CHIANG et al., 1994; CHIANG et al., 1995; BEVIGLIA et al., 1995).

\section{2-Metaloproteases}

Metaloproteases de venenos viperídicos têm sido descritas como responsáveis por muitas atividades, principalmente alguns processos fisiológicos como a fibrinólise e a coagulação. Também estão envolvidas na migração de células, organogênese, reparo tecidual, desenvolvimento embrionário, formação óssea, reprodução. E ainda são relacionadas a efeitos patológicos como a artrite e o câncer (HOOPER, 1994).

Estas enzimas pertencem, geralmente, à classe das zinco-metaloproteases e possuem em comum o sítio de ligação de zinco, caracterizado pela seqüência de aminoácidos HEXXHXXGXXHD (GOMIS-RUTH et al., 1993; BODE et al., 1993). Em adição ao sítio de ligação do zinco, estas glicoproteínas possuem ainda uma outra estrutura característica, também 
envolvida na ligação ao zinco, denominada "Met-Turn", representada pela seqüência de consenso CI/VM (HOOPER, 1994; BODE, et al., 1993).

Baseado na sua estrutura e função, as metzincinas podem ser agrupadas em quatro subfamílias (STONE; KROEGER; SANG, 1999): as astacinas (isoladas de um tipo de camarão de água doce), as matrixinas (MMPs- matrix metalloproteases), as reprolisinas (fazem parte desta subfamília as SVMPs- snakes venom metalloproteases e as ADAMs- a disintegrin-like and metalloprotease domain ou MDCs- metalloprotease/desintegrin /cystein domain) (BLOBEL, 1997), e as serralisinas (proteases bacterianas). As enzimas que constituem a família das metzincinas possuem uma organização multimodular com grande variabilidade, cujas funções e os tamanhos destas proteases são dependentes das combinações entre os diferentes domínios.

Todas as reprolisinas apresentam um pró-domínio e são ativadas pelo mecanismo “cysteine switch”, encontrado em metaloproteases de degradação de matriz (NAGASE, 1999).

As ADAMs, presentes em mamíferos e outros organismos, têm o mesma organização de domínios das metaloproteases de veneno adicionado o domínio EGF-like na porção C-terminal, sendo este um domínio transmembrânico e potencialmente sinalizador da cauda citoplasmática. Essas proteínas possuem propriedades adesivas e anti-adesivas; propriedades adesivas incluem a fusão do espermatozóide com o óvulo e a fusão muscular, e as propriedades anti-adesivas incluem a inibição do destino das células neurais em diferentes fases da embriogênese e extensão axônica em Drosophila (BLOBEL, 1997). Elas estão envolvidas em mecanismos derivados da atividade catalítica encontrado na conversora da enzima TNF- $\alpha$, TACE (ADAM 17) ( BLACK et al., 1997).

As SMVPs são sintetizadas na forma de precursores inativos ou zimogênicos, em que a região pró-enzima é relativamente grande (cerca de 200 aminoácidos), altamente conservada, e 
com uma seqüência de consenso (PKMCGVT) para ativação pelo mecanismo de "cysteineswitch" como proposto para metaloproteases matriciais (GRAMS et al., 1993). Esses precursores são rapidamente processados, na própria glândula, para tornarem-se enzimas funcionais (BJARNASON; FOX, 1994; HITE et al., 1994; SHIMOKAWA et al., 1996). Essas proteínas foram divididas em 4 classes (PI a PIV), de acordo com sua massa molecular e organização de domínios (Fig. 1.2). A classe PI inclui as SMVPs pequenas, com massa molecular aproximada de 24.000Da, e baixa ou nenhuma atividade hemorrágica. A classe PII inclui as proteínas de tamanho médio (BJARNASON; FOX, 1994) e libera as desintegrinas RGD no processamento proteolítico (YAMADA et al., 1999), com média atividade proteolítica.

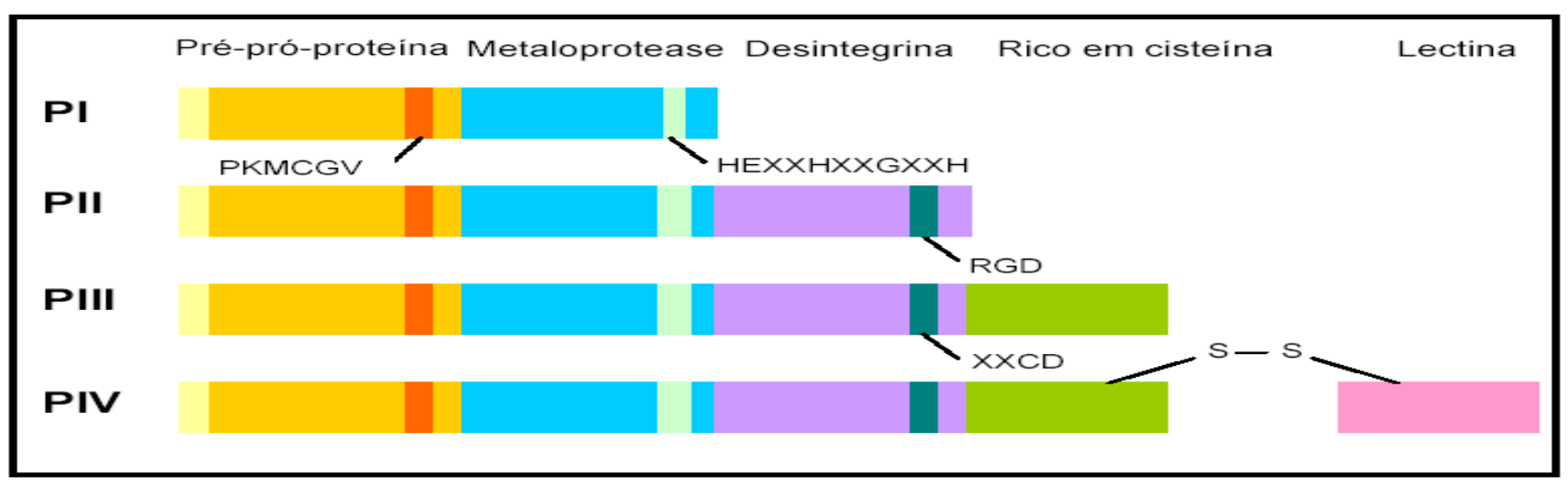

Figura 1.2 - Diagrama esquemático das estruturas das classes das metaloproteases de veneno de serpente (SVMPs). Os domínios não estão proporcionais ao tamanho real. (Extraído e adaptado de BJARNASON; FOX, 1994; COMINETTI, 2004)

Alguns estudos com os peptídeos de RGD mostram que esses induzem a quebra na região de contato em células do melanoma e rompimento do citoesqueleto de actina (CASTEL, 2000). Algumas desintegrinas RGD apresentam a capacidade de inibir tumores nas células da matriz extracelular de adesão (SHEU, 1994) e diminuição do número experimental de metástases. (TRIKHA, 1994; DANEN, 1998). Estas ligam-se preferencialmente as integrinas $\alpha_{5} \beta_{1}$ ou $\alpha_{v} \beta_{3}$ em diferentes tipos de células causando a inibição da adesão celular a fibronectina.(TRIKHA, 1994). 
Acutina e triflavina, duas desintegrinas RGD dos venenos de Angkistrodon acutus e Trimeresurus flavoviridis, respectivamente, inibem a angiogênese e induzem apoptose nas células endoteliais (YEH, 1998; SHEU, 1997).

A classe PIII é representada por hemorraginas grandes (aproximadamente $55 \mathrm{kDa}$ ) que provavelmente são as toxinas de maior atividade hemorrágica (BJARNASON; FOX, 1994). Elas têm um domínio tipo-desintegrina e um domínio rico em cisteína adicional, ao C-terminal do domínio tipo-desintegrina, que não é encontrado nas desintegrinas RGD. No domínio tipodesintegrina, o motivo RGD é substituído por um motivo D/ECD. Essas proteínas PIII inibem a agregação induzida por colágeno (ZHOU et al., 1995; DE LUCA et al., 1995). Alguns poucos membros da classe PIII têm sido descritos incluindo jararagina de veneno de Bothrops jararaca, atrolisina A e catrocollastatina de veneno de Crotalus atrox, alternagina de veneno de Bothrops alternatus (HITE et al., 1994; ZHOU et al., 1995; PAINE et al., 1992; SOUZA et al., 2000) e VAP1 e VAP2B (IGARASHI, 2007; TAKEDA, 2006). O termo tipo-desintegrina foi introduzido para diferenciar este grupo de proteínas das desintegrinas RGD. Essas proteínas tipodesintegrinas não se ligam a integrinas $\alpha_{\mathrm{II}} \beta_{3}, \alpha_{\mathrm{v}} \beta_{3}$ ou $\alpha_{5} \beta_{1}$, mas eles interagem com os receptores de colágeno, a integrina $\alpha_{2} \beta_{1}$ e inibem a adesão celular ao colágeno I (SOUZA et al., 2000)

A proteína VAP1 (proteína indutora de apoptose vascular) isolada do veneno Crotalus atrox é uma metaloprotease /desintegrina (classe PIII) que induz a apoptose vascular (ARAKI, 2002). A VAP1 liga-se a integrina $\alpha_{v} \beta_{3}$ dependente de RGD, inibindo a sinalização de proliferação de células endoteliais durante o crescimento de novos vasos sanguíneos (BROOKS, 1994; FRIEDLANDER, 1995).

A função dos três domínios nas atividades das moléculas da classe PIII ainda não é totalmente conhecida, e estudos com o objetivo de esclarecer suas funções são importantes para o 
desenvolvimento de novos fármacos. Algumas proteínas da classe PIII apresentam elevada atividade auto-proteolítica (liberando os domínios D e C), enquanto que em outras PIII esta atividade não é muito alta. Exemplos de autólise das P-III SVMPs isoladas, incluem a HR1A e HR1B da Trimeresurus flavoviridis, HT-1 do veneno de Crotalus ruber ruber, e brevilisina H6 da Gloydius halys brevicaudus, todas produzindo um homólogo do domínio tipo-desintegrina /rico em cisteína fragmentado(TAKEYA, 1993; FUJIMURA, 2000).

\section{3-Jararagina e Bothropasina}

Jararagina e bothropasina são duas SVMPs da classe PIII isoladas do veneno de Bothrops jararaca que apresentam alto grau de identidade, o que as caracteriza como isoformas. Estas proteínas apresentam, geralmente, a região N-terminal bloqueada por um resíduo de glutamil ciclizado (ácido piroglutâmico) e não é possível, portanto, caracterizá-las através de sequenciamento de N-terminal por degradação de Edman. Segundo a literatura, a jararagina e a bothropasina são obtidas do veneno através de diferentes protocolos de purificação.

A jararagina foi isolada pela primeira vez por Paine e colaboradores (PAINE et al., 1992) e é uma metaloprotease tipo-desintegrina (motivo ECD-Glu-Cys-Asp) com massa molecular calculada de 46,8 kDa, da classe PIII, com 421 aminoácidos na proteína após a modificação pós-traducional, que tem seu sítio catalítico dependente do zinco $\left(\mathrm{Zn}^{+}\right)$. Ela se liga ao domínio I da cadeia $\alpha_{2}$ e cliva a cadeia $\beta_{1}$ das integrinas de plaquetas que contribui para a inibição da agregação plaquetária induzida por colágeno (KAMIGUTI et al., 1996; MOURADA-SILVA et al., 2001). Devido à atividade fibrinolítica, a jararagina possui um efeito inibitório na agregação plaquetaria in vitro e induz o desligamento das células endoteliais vasculares e da membrana basal vascular (KAMIGUTI et al., 1991, 1994). Injeções subcutâneas de jararagina 
têm causado hemorragia sistêmica junto com trombocitopenia (redução do número de plaquetas no sangue) em experimentos animais (KAMIGUTI et al., 1991). Esses achados, juntos com a observação de ineficácia da jararagina na inibição do plasma (KAMIGUTI et al., 1994), sugere que essa metaloprotease age não somente no local, mas numa hemorragia sistêmica. Estudos recentes têm mostrado uma forma proteoliticamente estável (a jararagina completa) e uma forma instável (forma processada sem o domínio metaloprotease, conhecida como jararagina-C). A Jararagina C é um potente inibidor de agregação plaquetária estimulada pelo colágeno (MOURADA-SILVA et al., 2003; USAMI, 1994).

A bothropasina foi isolada pela primeira vez por Mandelbaun (MANDELBAUM et al., 1982) e também é uma metaloprotease/ tipo-desintegrina da classe PIII, constituída de 421 resíduos e com massa molecular estimada de 46,8 $\mathrm{kDa}$. Essa proteína também apresenta atividade hemorrágica (MANDELBAUN et al., 1982), seguido por mionecrose e necrose arterial em experimentos em ratos (QUEIROZ, 1985). Por não ser possível seqüênciar o N-terminal, a seqüência de aminoácidos conhecida da jararagina é a deduzida a partir do cDNA. A seqüência de aminoácidos da bothropasina foi determinada através da resolução da estrutura da proteína (MUNIZ, 2007) (Fig. 1.3). As proteínas jararagina e bothropasina apresentam aproximadamente 95\% de identidade seqüencial, determinada através do alinhamento entre suas seqüências de aminoácidos (Fig. 1.4). 


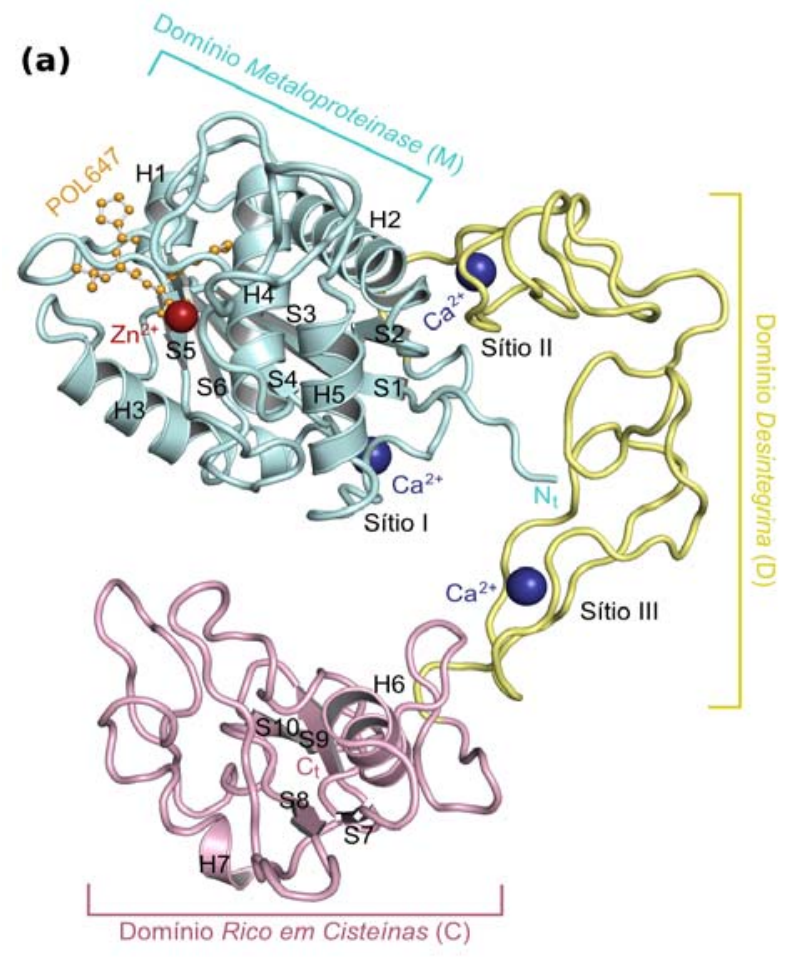

Figura 1.3 - Estrutura da bothropasina complexada com o inibidor POL647. Estrutura revelando a presença de três domínios: o domínio catalítico (M); o domínio tipo-desintegrina (D) e o domínio rico em cisteínas (C). Os domínios M, D e C estão representados nas cores cian, amarela e rosa, respectivamente. (MUNIZ, 2007)

\begin{tabular}{|c|c|c|}
\hline \multirow{3}{*}{$\begin{array}{l}\text { Jararagina } \\
\text { Bothropasina }\end{array}$} & \multicolumn{2}{|l|}{ Domínio catalítico (M) } \\
\hline & EQQRYDPYKYIEFFFVVVDQGTVTKNNGDLDKIKARMYELANIVNEIFRYLYMHVALVGLEIWSNGDKITVKPDVDYTLNSFAEWRKTDLéLTRKKHDNAQLLTAIDF & 106 \\
\hline & EQQ Y P Y E F VVDQG VTKNNGDLDKIKARMYELANIVNEI RYLYMH ALVGLEIWSNNGDKITVKPDVDYTLNSFAEWRKTDLLTRKKHDNAQLLTAIDF & 106 \\
\hline & Domínio catalítico(M) & $\mathrm{a}(\mathrm{D})$ \\
\hline Jararagina & NGPTIGYAYIGSMCHPKRSVGIVQDYSPINLVVAVIMAHEMGHNLGIHHDTGSCSCGDYPCIMGPTISNEPSKFFSNCSYIQCWDFIMNHNPECIINEPLGT DIISPPVCG & 217 \\
\hline Bothropasina & $\begin{array}{l}\text { NGPTIGYAYIGSMCHPKRSV IV DYSPINLVVAVIMAHEMGHNLGIHHDT CSCGDYPCIMGPTISNEPSKFFSNCSYIQCWDFIM NP GI NEPLGT DI SPPVCG } \\
\text { Ca }{ }^{2+}-\text { Sitio I }\end{array}$ & 217 \\
\hline & Dominio rico em cisténa (C) & \\
\hline Jararagina & NELLEVGEECDCGTPENCQNECCDAATCKLKSGSQCGHGDCCEQCKFSKSGTECRASMSECDPAEHCTGQSSECPADVFHKNGQ PCLDNYGYCYNGNCPIMYHQCY & 323 \\
\hline Bothropasina & NELLEVGEECDCGTPENCQNECCDAATCKLKSGSQCGHGDCCEQCKFSKSGTECRASMSECDPAEHCTGQSSECPADVFHKNGQ PCLDNYGYCYNGNCPIMYHQCY & 323 \\
\hline & Domínio rico em Cistéina ( C) & \\
\hline Jararagina & ALFGADVYEAEDSCFKDNQKGNYYGYCRKENGKKIPCAPEDVKCGRLYCKDNSPGQNNPCKMFYSNDDEHKGMVLPGTKCADGKVCSNGHCVDVATAY & 421 \\
\hline Bothropasina & ALFGADVYEAEDSCFKDNQKGNYYGYCRKENGKKIPCAPEDVKCGRLYCKDNSPGQNNPCKMFYSNDDEHKGMVLPGTKCADGKVCSNGHCVDVATAY & 421 \\
\hline
\end{tabular}

Figura 1.4: Alinhamento entre as seqüências da jararagina e bothropasina. Quando comparadas em um alinhamento, 19 resíduos de aminoácidos se diferenciam entre elas (mostrado por letras verdes e azuis). 


\section{4-Alternagina}

A Alternagina é uma proteína da classe PIII das SVMPs, contendo os domínios metaloprotease/tipo-desintegrina e rico em cisteína, isolada do veneno de Bothrops alternatus (SOUZA et al.,2000). Alternagina-C (Alt-C) é a resultante do processamento da alternagina, e é constituída pelos domínios tipo-desintegrina e domínio rico em cisteína. Foi demonstrado que alternagina-C é um potente inibidor da ligação do colágeno à integrina $\alpha_{2} \beta_{1}$ em células K562 e induz a expressão do fator de crescimento do endotélio vascular (vascular endothelial growth factor- VEGF) do fibroblasto e nas células proliferativas do endotélio (COMINETTI et al., 2004). Além disso, a alternagina possui uma alta atividade edematogênica e miotóxica e, apesar de ter uma fraca atividade proteolítica, ela é capaz de degradar o fibrinogênio. Logo, essa enzima contribui na ação do envenenamento bothrópico (GAY et al., 2005).

Ramos e colaboradores (RAMOS et al., 2007) apresentaram pela primeira vez a atividade proangiogênica das proteínas do grupo das desintegrinas da classe PIII das toxinas de veneno de serpente. É possível que outros membros possam ter atividades miméticas a da Alt-C.

Quando imobilizada em placa, alt-C promove a adesão às integrinas $\alpha_{2} \beta_{1}$ transfectadas das células K562, mas não controla a adesão das células. Alt-C não se liga às integrinas $\alpha_{\mathrm{IIb}} \beta_{3}, \alpha_{5} \beta_{1}$, $\alpha_{\mathrm{v}} \beta_{3}, \alpha_{1} \beta_{1}, \alpha_{9} \beta_{1}$ e $\alpha_{4} \beta_{1}$ (SOUZA et al., 2000). Em neutrófilos humanos, alt-C pode induzir migração via sinalização das integrinas, com ativação da adesão localizada da quinase (FAK) e essa associação com a fosfatidilinositol 3-quinase (PI3-quinase), direcionando um aumento na translocação nuclear da F-actina e Erk-2 (MARIANO-OLIVEIRA, 2003). 


\section{Capítulo 2- Objetivos}

A motivação para o desenvolvimento deste projeto foi $o$ fato de que as metaloproteases/desintegrinas, proteínas pertencentes à classe PIII das SVMPs, embora bastante estudadas, ainda apresentam diversos aspectos a serem elucidados. Ainda não são conhecidos, por exemplo, qual é o domínio que exerce a função de ligação com integrinas e o motivo seqüêncial/estrutural que fornece especificidade a essas proteínas.

Os objetivos gerais deste projeto foram os estudos, com diferentes abordagens, de metaloproteases/desintegrinas oriundas de venenos de serpentes. As proteínas estudadas foram a jararagina e bothropasina, isoladas de veneno de B. jararaca e alternagina, isolada de

\section{B.alternatus.}

Os objetivos específicos foram:

- Estudos de autólise da bothropasina e da alternagina. O objetivo foi verificar a autólise sofrida pelas proteínas e fazer uma comparação de seus processos de autólise.

- Estudos de aspectos físico-químicos e estruturais de bothropsina e alternagina em solução, através de técnicas espectroscópicas (dicroísmo circular e fluorescência). O objetivo foi verificar se as proteínas apresentam comportamentos semelhantes frente a agentes desnaturantes, tentando correlacionar com os resultados dos estudos de autólise.

- Estudos das metaloproteases/desintegrinas isoladas de veneno de B. jararaca em diferentes procedimentos cromatográficos descritos na literatura. $O$ objetivo foi verificar a possibilidade, descrita na literatura, de que a separação das isoformas bothropasina e jararagina possa ser determinada pelos protocolos de purificação. 


\section{Capítulo 3 - Metodologia}

\section{1-Purificação das proteínas}

\subsection{1-Purificação da alternagina}

O veneno liofilizado de Bothrops alternatus foi gentilmente fornecido pelo Laboratório de Herpetologia do Instituto Butantan, a partir de diversas amostras extraídas de diferentes exemplares de serpentes.

A purificação da alternagina foi realizada conforme metodologia padronizada por Souza e colaboradores (SOUZA et al., 2000) com algumas modificações. Para tal, 50 mg de veneno liofilizado de B. alternatus foi solubilizado em 1,2 ml de tampão fosfato de sódio 10 mM pH 7,2, e aplicado em coluna cromatográfica contendo resina de troca iônica ANX Sepharose Fast Flow(GE Life Science-1 ml), previamente equilibrada com a mesma solução tamponante. A coluna estava acoplada a um sistema HPLC automatizado (GE Life Science), o qual permaneceu a $6^{\circ} \mathrm{C}$ durante todo o processo de purificação da proteína. Antes de ser aplicada na coluna, a amostra foi centrifugada por 20 minutos a 10.000 rpm, para retirar partículas que não foram solubilizadas.

A eluição das proteínas não aderidas à resina da coluna foi realizada com $10 \mathrm{~mL}$ do tampão acima descrito em fluxo de $0,5 \mathrm{~mL} / \mathrm{min}$. O processo de eluição foi um gradiente composto por dois estágios: gradiente linear de 30 vezes o volume de coluna $(30 \mathrm{ml})$ até $100 \%$ de Cloreto de sódio ( $\mathrm{NaCl}$ ) 0,3 M em mesmo tampão e $10 \mathrm{ml}$ de solução a 100\% de $\mathrm{NaCl}$.

As amostras contendo proteína com massa molecular aproximada de $55 \mathrm{kDa}$, estimada por SDS-PAGE (LAEMMLI, 1970) foram reunidas, concentradas a $1 \mathrm{~mL}$ e aplicada em uma 
coluna de exclusão molecular Superdex 75 (GE Life Science, 1,6 cm x $60 \mathrm{~cm}, 120 \mathrm{~mL}$ ), equilibrada com tampão $10 \mathrm{mM}$ de fosfato de sódio $\mathrm{pH}$ 7,2 e $0,3 \mathrm{M}$ de $\mathrm{NaCl}$. A eluição das proteínas foi realizada a um fluxo constante de $0,5 \mathrm{ml} / \mathrm{min}$ e foram coletadas frações de $1 \mathrm{ml}$. As cromatografias foram monitoradas pela leitura de absorbância a $280 \mathrm{~nm}$.

As frações de alternagina foram analisadas quanto à pureza das amostras através de eletroforese em gel de poliacrilamida (SDS-PAGE), condições desnaturantes, e com $\beta$ mercaptoetanol, condições redutoras (LAEMMLI, 1970).

A massa molecular aparente das proteínas de interesse foi estimada através de um padrão utilizando proteínas de massa molecular conhecidas, de 20,1 a $66 \mathrm{kDa}$, preparado no nosso laboratório com as proteínas soroalbumina bovina (BSA), ovoalbumina, anidrase carbônica bovina e inibidor de tripsina de soja, todas obtidas da Sigma.

As amostras eluídas da coluna Superdex75 contendo a alternagina (MM aproximadamente $55 \mathrm{kDa}$ ) foram reunidas, levadas à diálise contra tampão Tris $20 \mathrm{mM} \mathrm{pH8,0} \mathrm{e} 20 \mathrm{mM} \mathrm{de} \mathrm{NaCl}$ (duas trocas de tampão) e concentradas a $250 \mu \mathrm{l}$ para medidas de dicroísmo circular e fluorescência. Para estudos de autólise, as amostras usadas foram as eluídas da coluna Superdex 75 contendo majoritariamente a banda de $55 \mathrm{kDa}$ do SDS-PAGE, que corresponde à alternagina.

\subsection{2- Purificação de metaloprotease/desintegrina (MD) do veneno de B. jararaca}

O veneno liofilizado de B. jararaca foi gentilmente fornecido pelo Laboratório de Herpetologia do Instituto Butantan, a partir de diversas amostras extraídas de diferentes exemplares de serpentes. 
A purificação da MD foi realizada seguindo três metodologias diferentes: a padronizada por Mandelbaun e colaboradores (MANDELBAUN et al., 1982), a metodologia descrita por Muniz (MUNIZ, 2007) e ainda a descrita por Paine e colaboradores (PAINE et al., 1992).

No primeiro método foi usado $100 \mathrm{mg}$ de veneno liofilizado de B. jararaca que foi solubilizado em $10 \mathrm{ml}$ de tampão $0,9 \%(0,154 \mathrm{M})$ de $\mathrm{NaCl}$ e lentamente foi sendo adicionado 2,91 g de sulfato de amônio (saturação de 50\%). Para misturar bem o sulfato de amônio com a solução contendo proteína foi deixada, em gelo, por dez minutos com agitação constante. Após misturar, a amostra foi centrifugada a $20.000 \mathrm{~g}$ por 20 minutos. O sobrenadante foi separadado em um tubo tipo falcon e o "pellet" foi ressuspendido em $2 \mathrm{ml}$ de tampão 0,05 M de Tris- $\mathrm{HCl}$ pH7,5 contendo $1 \mathrm{mM}$ de $\mathrm{CaCl}_{2}$. A solução com o "pellet" foi aplicada em coluna contendo resina troca iônica DEAE-cellulose (GE Life Science -1,0 cm x $20 \mathrm{~cm}$ ), equilibrada com solução tamponante. A coluna estava acoplada a um sistema HPLC automatizado (GE Life Science) e permaneceu a $6^{\circ} \mathrm{C}$ durante o processo de purificação da proteína.

A remoção das proteínas não aderidas à resina da coluna foi realizada com $140 \mathrm{ml}$ do tampão acima descrito e o fluxo de $1 \mathrm{~mL} / \mathrm{min}$. O processo de eluição foi um gradiente composto por dois estágios: 3 vezes o volume de coluna (total de $60 \mathrm{ml}$ ) de $20 \%$ de $\mathrm{NaCl}$ 0,5 M em mesmo tampão e $40 \mathrm{~mL}$ de solução a $40 \%$ de $0,5 \mathrm{M} \mathrm{NaCl}$ em 0,05 M de Tris-HCl pH7,2 contendo $1 \mathrm{mM}$ de $\mathrm{CaCl}_{2}$. As amostras contendo proteína com massa molecular aproximada de $55 \mathrm{kDa}$ (estimada por SDS-PAGE) foram aliquotadas $(500 \mu \mathrm{L})$ e congeladas no $-80^{\circ} \mathrm{C}$.

No método de Muniz (MUNIZ, 2007) usou-se 50mg de veneno de B. jararaca solubilizado em $1,2 \mathrm{ml}$ de tampão $20 \mathrm{mM}$ de Tris- $\mathrm{HCl}$ pH8,0 e centrifugado por 20 minutos a 10.000rpm. O sobrenadante foi aplicado na DEAE sepharose Fast-Flow (GE Life Science, volume de 70ml), já equilibrada com tampão anterior. 
As proteínas que não aderiram na resina da coluna foram removidas com aproximadamente, $210 \mathrm{ml}$ do tampão de equilíbrio. A fase de eluição foi um gradiente de três fases: gradiente linear de $700 \mathrm{ml} \mathrm{a} 40 \%$ de $\mathrm{NaCl}$ 0,5M em mesmo tampão; rápido gradiente linear de 40 a $100 \%$ de $20 \mathrm{mM}$ de Tris- $\mathrm{HCl}$ pH 8,0 e $0,5 \mathrm{M}$ de $\mathrm{NaCl}$ e $120 \mathrm{~mL}$ de solução a $100 \%$ de $20 \mathrm{mM}$ de Tris- $\mathrm{HCl} \mathrm{pH} 8,0$ e 0,5M de $\mathrm{NaCl}$. Após esse passo, parte das amostras foram congeladas no $-80^{\circ} \mathrm{C}$ para os experimentos de espectrometria de massas.

A cromatografia foi realizada em fluxo constante de $3 \mathrm{~mL} / \mathrm{min}$ e as frações contendo proteínas com massa molecular de aproximadamente $55 \mathrm{kDa}$ (estimada por SDS-PAGE), foram reunidas e concentradas a 1mL, para aplicação em uma coluna superdex 75 (GE Life Science, $120 \mathrm{~mL}$ ), equilibrada com o tampão $20 \mathrm{mM}$ de Tris- $\mathrm{HCl}$ pH 8,0 e 0,5M de $\mathrm{NaCl}$. A eluição das proteínas foi realizada a um fluxo de $0,5 \mathrm{~mL} / \mathrm{min}$, em temperatura de $4^{\circ} \mathrm{C}$ e foram coletadas frações de $1 \mathrm{ml}$.

As amostras eluídas da coluna Superdex75 contendo a MD (massa molecular aproximadamente $55 \mathrm{kDa}$ ) foram reunidas, levadas à diálise contra tampão Tris- $\mathrm{HCl} 20 \mathrm{mM}$ pH8,0 e $20 \mathrm{mM}$ de $\mathrm{NaCl}$ (duas trocas de tampão) e concentradas a $250 \mu 1$ para medidas de dicroísmo circular e fluorescência. Para estudos de autólise as amostras usadas foram as eluídas da coluna Superdex 75 contendo a proteína mais pura.

Na metodologia de Paine e colaboradores (PAINE et al., 1992), a proteína foi purificada a partir de $10 \mathrm{mg}$ do veneno e ressuspendido em 1,2ml de tampão 20mM de TRis-HCl pH 7,4 e 2M de sulfato de amônio. Essa amostra foi aplicada numa coluna de interação hidrofóbica PhenylSuperose (GE- Life Science -HR5/5-1ml), equilibrada com o mesmo tampão da amostra, e as proteínas que não ligaram na coluna foram removidas com $7 \mathrm{ml}$ desse tampão. A eluição foi feita num gradiente linear de $20 \mathrm{ml}$ até $100 \%$ de tampão $20 \mathrm{mM}$ de Tris- $\mathrm{HCl}$ pH7,4 e $10 \mathrm{ml}$ de $100 \%$ de 
solução a $100 \%$ de tampão $20 \mathrm{mM}$ de Tris- $\mathrm{HCl}$ pH7,4. A cromatografia foi realizada a um fluxo constante de $0,5 \mathrm{ml} / \mathrm{min}$ e foram separadas as frações que tinham proteínas com peso molecular aproximado de $55 \mathrm{kDa}$, essas foram aliquotadas em $500 \mu \mathrm{l}$ e congeladas no $-80^{\circ} \mathrm{C}$.

\section{2-Dosagem de proteína}

As proteínas foram dosadas pelo método de Bradford (BRADFORD, 1976) no qual é usado o corante Coomassie Brilliant Blue G-250 para verificar a presença da proteína. Em média usou-se $10 \mu \mathrm{l}$ de amostra e misturado com $200 \mu \mathrm{l}$ de Bradford e $790 \mu l$ de água miliQ. Depois foi medido a absorção em 595nm e partir daí foi calculada, a partir de valores de uma curva padrão, sua concentração. A interação do corante com a proteína é completada em dois minutos, permanecendo estável por aproximadamente uma hora.

\section{3- Preparação das amostras para espectrometria de massa.}

As amostras resultantes dos métodos de purificações de Mandelbaun (MANDELBAUN et al., 1982), Muniz (MUNIZ, 2007) e de Paine (PAINE et al., 1992) foram descongeladas do $-80^{\circ} \mathrm{C}$ em gelo. Após descongelar completamente, as amostras foram preparadas para serem aplicadas em gel de eletroforese. As amostras foram aplicadas em SDS-PAGE e após corar com corante Comassie Blue e descorar com ácido acético 10\%, as bandas referentes às proteínas, com aproximadamente $55 \mathrm{kDa}$, foram cortadas e as proteínas foram eluídas do gel com $100 \mu \mathrm{L}$ de água miliQ. As proteínas eluídas dos géis serão digeridas com tripsina e analisadas pelo espectrômetro de massas em colaboração com o Prof. Dr. José César Rosa do Departamento de Biologia Celular 
e Molecular e Bioagentes Patogênicos da Faculdade de Medicina de Ribeirão Preto da Universidade de São Paulo.

\section{4-Autólise da alternagina e da bothropasina}

Após os processos de purificação da alternagina pelo método modificado de Souza e colaboradores (SOUZA et al., 2000), e da M/D de B. jararaca pelo protocolo de Muniz (MUNIZ, 2007), nomeada pelo autor de bothropasina, foram medidas a concentração das proteínas. Soluções das duas proteínas foram mantidas iguais em aproximadamente $0,138 \mathrm{mg} / \mathrm{mL}$. Os processos de autólise da alternagina e da bothropasina foram analisados a $25^{\circ} \mathrm{C}$ e a $6^{\circ} \mathrm{C}$, temperaturas usadas geralmente no processo de purificação e em diferentes intervalos de tempo (1h, 6h, 8h, 11h, 24h, 33h, 2, 3, 4, 7, 11, 15 dias). Nessas condições, alíquotas de 30 $\mu \mathrm{L}$ foram retiradas e analisadas em SDS-PAGE.

As amostras que sofreram autólise foram aplicadas em gel SDS-PAGE e as bandas do gel foram transferidas para uma membrana de nitrocelulose e analisadas por imunoblotting. O anticorpo utilizado foi o anticorpo contra alt-C produzido em coelho, fornecido pela Profa. Dra. Heloisa Selistre-de-Araújo, do Departamento de Ciências Fisiológicas da Universidade Federal de São Carlos. Após a reação com o anticorpo específico, a membrana reagiu com IgG de coelho. Ao final do processo a membrana foi revelada com kit da Biorad específico.

\section{5-Medidas de dicroísmo circular}

As medidas foram realizadas em um espectropolarímetro Jasco (modelo J-715) num intervalo de comprimento de onda de 215 a $250 \mathrm{~nm}$. As amostras continham aproximadamente 
$0,14 \mathrm{mg} / \mathrm{mL}$ de proteína e utilizou-se uma cubeta cilíndrica de $0,1 \mathrm{~cm}$ de caminho óptico. $\mathrm{O}$ parâmetro variado foi a concentração de hidrocloreto de guanidina no intervalo de $0 \mathrm{M}$ a $7 \mathrm{M}$. Para realização das medidas as amostras das proteínas alternagina e $\mathrm{M} / \mathrm{D}$, isolada por Muniz (MUNIZ, 2007) intitulada de bothropasina, ambas em solução tampão 20 mM Tris pH 8,0 e 20 $\mathrm{mM}$ de $\mathrm{NaCl}$, foram incubadas por o período de uma hora em diferentes concentrações de hidrocloreto de guanidina e em seguida o espectro foi medido. A desnaturação foi acompanhada pela mudança na elipsidade em $220 \mathrm{~nm}$ induzida pelo aumento da concentração de hidrocloreto de guanidina. As elipsidades das diferentes concentrações de hidrocloreto de guanidina, monitoradas em comprimento de onda de $220 \mathrm{~nm}$, foram normalizadas, com menor elipcidade valendo 0 e maior elipcidade considerada 1 . A partir dessa normalização foram encontradas a frações de proteína desnaturada em função da concentração do agente desnaturante.

\section{6 - Medidas fluorimétricas}

Os espectros de emissão de fluorescência foram monitorados no intervalo de comprimento de onda de 290 a $450 \mathrm{~nm}$ quando a excitação foi realizada em $280 \mathrm{~nm}$. Quando a excitação foi realizada em $295 \mathrm{~nm}$, os espectros de fluorescência foram medidos no intervalo de comprimento de onda de $300 \mathrm{~nm}$ a $450 \mathrm{~nm}$. As cubetas utilizadas tinham $0,5 \mathrm{~cm}$ de caminho óptico e volume de $0,5 \mathrm{~mL}$. As amostras utilizadas para as medidas de fluorescência e dicroísmo circular foram às mesmas. As medidas de fluorescência eram feitas subsequentemente após as análises de dicroísmo. Todas as medidas foram feitas em triplicatas. O espectrofluorímetro utilizado foi um ISS (mod. K2). A desnaturação foi monitorada através da variação do centro de massa do espectro, expressa em termos de fração de proteína desnaturadas $\left(f_{d}\right)$, em função da 
concentração de hidrocloreto de guanidina em mesmo tampão. $O$ centro de massa $\left(\lambda_{\mathrm{CM}}\right)$ foi calculado de acordo com a seguinte equação (BOTELHO et al, 2003)

$$
\lambda_{\mathrm{CM}}=\sum \lambda(\lambda) / \sum I(\lambda)
$$

onde $\lambda$ é o comprimento de onda de emissão e $\mathrm{I}(\lambda)$ representa a intensidade da emissão no comprimento de onda $\lambda$.

As medidas de centro massa em diferentes concentrações foram normalizadas, considerando o maior valor com 1 e o menor como 0. A partir da normalização foram encontradas as frações

de proteínas desnaturadas. 


\section{Capítulo 4-Resultados e discussão}

\section{1-Estudos de Isolamento de metaloproteases/desintegrinas (MD) de veneno de $B$. jararaca.}

Recentemente, o nosso grupo de pesquisa estudou a estrutura tridimensional de uma MD isolada de veneno de B. jararaca (MUNIZ, 2007), a partir de proteína purificada segundo a metodologia descrita na literatura para o isolamento da jararagina (PAINE et al., 1992). No entanto, os mapas de densidade eletrônica mostraram que se tratava da molécula da isoforma da jararagina, a molécula de bothropasina. As isoformas bothropasina e jararagina, isoladas do veneno da B. jararaca, diferenciam-se somente por dezenove resíduos de aminoácidos. As duas proteínas apresentam o $\mathrm{N}$-terminal bloqueado por um resíduo de glutamil ciclizado, por isso não é possível caracterizá-las por degradação de Edman. Estudos da literatura indicam que as formas usadas para obter as duas isoformas são diferentes métodos cromatográficos (PAINE et al., 1992; MANDELBAUM et al., 1982). Devido à alta identidade entre as duas isoformas $(95,4 \%)$ e aos valores semelhantes de ponto isoelétrico das mesmas (5,04 para bothropasina e 5,08 para jararagina), parece surpreendente que o uso de resinas cromatográficas consiga levar ao isolamento de uma das isoformas em detrimento de outra. É possível que alguma das isoformas seja majoritária quando uma metodologia específica é utilizada.

Assim, nosso objetivo neste trabalho foi utilizar as diferentes metodologias descritas na literatura e verificar qual é a isoforma isolada em maior proporção em cada uma das metodologias. Também utilizamos duas diferentes fontes de veneno, um fornecido pelo Instituto Butantan e outro fornecido pelo Prof. Dr. Andreimar M. Soares do Departamento de Análises Clínicas, Toxicológicas e Bromatológicas da Faculdade de Ciências Farmacêuticas de Ribeirão 
Preto da Universidade de São Paulo. Assim, a técnica de espectrometria de massas poderia ser uma ótima alternativa para a caracterização das proteínas isoladas nos diferentes métodos. Para facilitar (agilizar) os processos de análise das proteínas isoladas nos diferentes processos nós fizemos as primeiras etapas de purificação seguindo a literatura e utilizamos, para a análise por espectrometria de massas, a metodologia de retirar amostra de gel de poliacrilamida já que a técnica requer baixa quantidade de amostra para ser sequenciada.

Existem na literatura dois trabalhos citando o isolamento de bothropasina. Um dos métodos é o descrito por Mandelbaum e colaboradores (MANDELBAUM et al., 1982). Seguindo esse procedimento para o isolamento o veneno bruto de B. jararaca foi ressuspendido em tampão $0,9 \%$ de $\mathrm{NaCl}$ e levado à precipitação com solução com $50 \%$ de sulfato de amônio. Após a precipitação, o precipitado foi ressuspendido com tampão $0,05 \mathrm{M}$ de Tris $\mathrm{pH} 7,5,1 \mathrm{mM}$ de $\mathrm{CaCl}_{2} \mathrm{e}$ a solução foi aplicada em coluna de troca iônica DEAE cellulose. A figura 4.1 ilustra o perfil cromatográfico desta etapa e o gel SDS-PAGE correspondente às frações eluídas da coluna. As frações contendo proteína com massa molecular próxima a 55kDa (indicadas na figura 4.1), continham a MD de B. jararaca. 


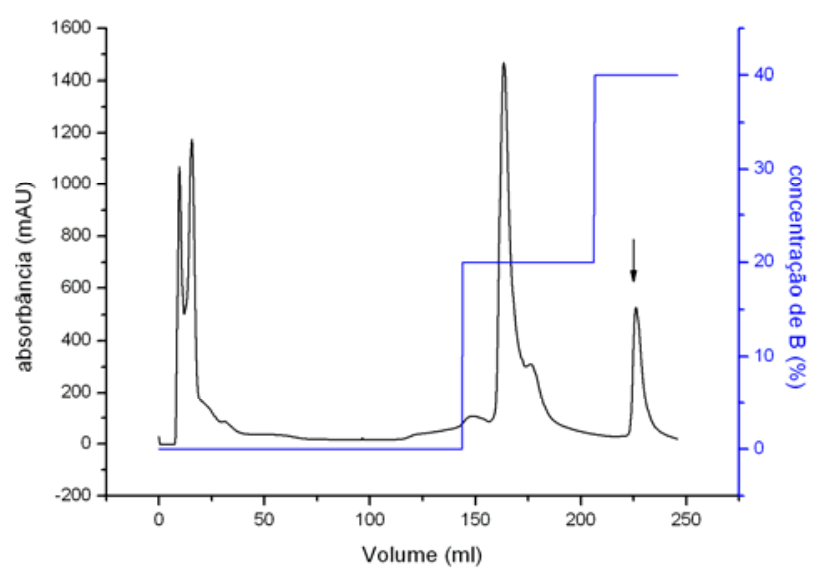

(a)

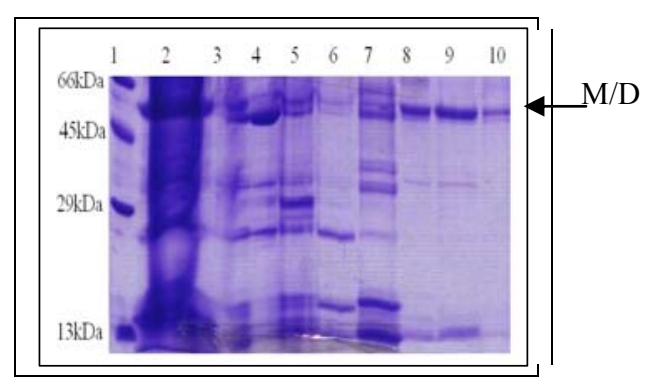

(b)

Figura 4.1: Análise do processo de purificação da bothropasina pelo método de Mandelbaum e colaboradores (MANDELBAUM et al., 1982). (a) Perfil cromatográfico da coluna DEAE cellulose, onde tampão A é o tampão $0,05 \mathrm{M}$ de Tris- $\mathrm{HCl}, 1 \mathrm{mM}$ de $\mathrm{CaCl}_{2} \mathrm{pH} 7,5$ e tampão $\mathrm{B}$ é o tampão de A acrescido de $0,5 \mathrm{M}$ de $\mathrm{NaCl}$ (a linha azul representa os gradientes de concentração de $\mathrm{NaCl}$ usados) :(b) Gel SDSPAGE das frações eluídas na coluna DEAE cellulose, coluna 1, padrão de massa molecular; colunas 2 e 3 , pellet e sobrenadante da precipitação com sulfato de amônio, respectivamente; colunas 4 e 5 , frações eluídas da coluna com tampão A; colunas 6 e 7, frações eluídas com $20 \%$ de tampão B e colunas 8,9 e 10 , frações eluídas da coluna cromatográfica com $40 \%$ de tampão B. A seta mostra as colunas com uma banda de $55 \mathrm{kDa}$.

Recentemente, outra metodologia para isolar bothropasina foi descrita na literatura e utilizada neste trabalho (MUNIZ, 2007). Neste método, o veneno bruto de B. jararaca ressuspendido em tampão $20 \mathrm{mM}$ de Tris- $\mathrm{HCl}$ pH 8,0 foi aplicado em coluna de troca iônica DEAE sepharose. A figura 4.2 ilustra o perfil cromatográfico desta coluna e o SDS-PAGE correspondente às frações eluídas. As frações contendo proteína com massa molecular próxima a $55 \mathrm{kDa}$ (indicadas na figura 4.2), correspondem à proteína estudada. 


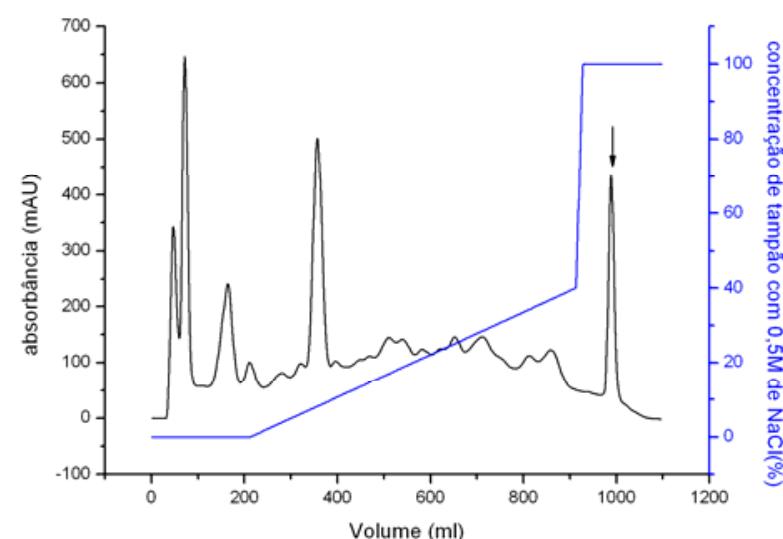

(a)

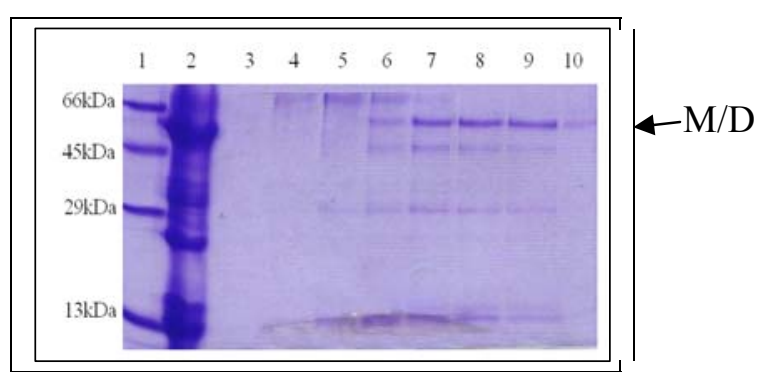

(b)

Figura 4.2: Análise do processo de purificação da bothropasina pelo método de Muniz (MUNIZ, 2007). (a) Perfil cromatográfico da coluna DEAE sepharose, onde se usa tampão $20 \mathrm{mM}$ de Tris- $\mathrm{HCl}$ com $\mathrm{pH} 8,0$ (a linha azul representa o gradiente salino utilizado); (b) SDS-PAGE das frações da figura 4.2 (a): coluna 1 , padrão de massa molecular; coluna 2 , veneno bruto $(50 \mathrm{mg} / \mathrm{ml})$; colunas 3 a 6 , frações eluídas até com $100 \%$ de tampão $0,5 \mathrm{M}$ de $\mathrm{NaCl}$ e colunas 7 a 10, frações eluidas com $100 \%$ de tampão $0,5 \mathrm{M}$ de $\mathrm{NaCl}$.

A purificação da isoforma jararagina é descrita na literatura por Paine e colaboradores (PAINE et al., 1992). Esta isoforma tem sido bastante estudada sob o ponto de vista de atividade biológica e todos os trabalhos usam o procedimento de Paine para o isolamento da jararagina. Utilizando esse método, o veneno de B. jararaca foi ressuspendido em tampão $20 \mathrm{mM}$ de Tris$\mathrm{HCl}$ pH 7,4, 2M de sulfato de amônio e aplicado em resina hidrofóbica phenyl-superose. O perfil cromatográfico desta coluna e o gel correspondente a essa cromatografia estão representados na Figura 4.3. As frações contendo proteína com massa molecular próxima a 55kDa (indicadas na figura 4.3), correspondem à proteína estudada. 


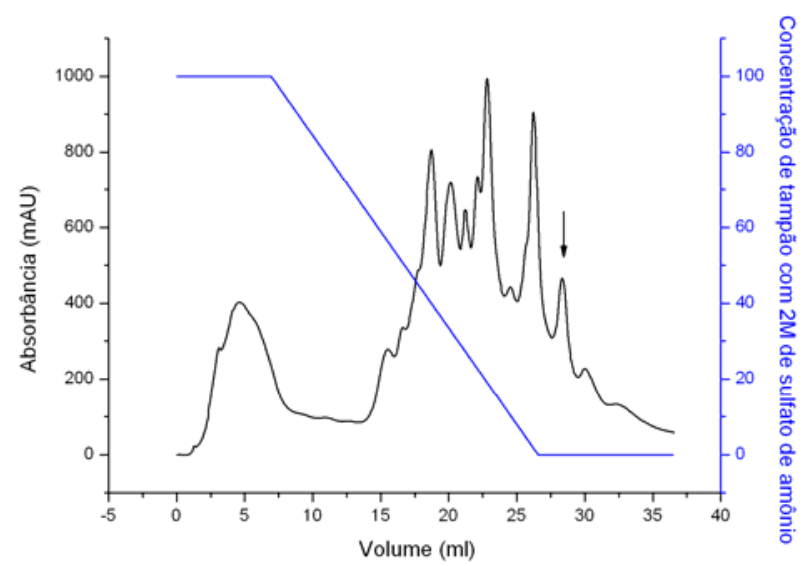

(a)

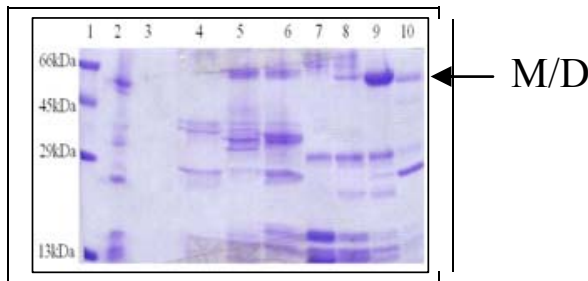

(b)

Figura 4.3: Análise do processo de purificação da jararagina, segundo o método de Paine e colaboradores (PAINE et al.,1992). (a) Perfil cromatográfico da coluna com a resina hidrofóbica phenyl-superose, onde se usa tampão $20 \mathrm{mM}$ de Tris- $\mathrm{HCl}$ com $\mathrm{pH} 7,4$ (a linha azul representa gradiente linear de 100 a $0 \%$ de tampão com 2M de sulfato de amônio): $10 \mathrm{mg}$ de veneno de B. jararaca aplicados na coluna; (b) SDSPAGE das frações da figura 4.3 (a): coluna 1, padrão de massa molecular; coluna 2, veneno bruto $(10 \mathrm{mg} / \mathrm{ml})$; colunas 3 a 8 , frações eluídas até com $0 \%$ de tampão $2 \mathrm{M}$ de sulfato de amônio e colunas $9 \mathrm{e}$ 10 , frações eluidas com $0 \%$ de tampão com $2 \mathrm{M}$ de sulfato de amônio. A seta no perfil cromatográfico indica o pico, que as amostras com $55 \mathrm{kDa}$ foram eluídas e no SDS-PAGE estão indicadas as bandas dessa proteínas.

Após essa etapa de purificação, as amostras de proteínas com massa molecular aproximada de $55 \mathrm{kDa}$ provenientes das três purificações (e que correspondem, teoricamente, a bothropasina e jararagina) foram aplicadas em gel preparativo de poliacrilamida, extraídas do gel e dosadas. As amostras serão analisadas por espectrometria de massas em colaboração com o Prof. Dr. José César Rosa do Departamento de Biologia Celular e Molecular e Bioagentes Patogênicos, da Faculdade de Medicina de Ribeirão Preto, USP.

Após essas análises, espera-se poder confirmar qual isoforma é a majoritária em cada um dos três diferentes métodos utilizados para isolamento de metaloproteases/desintegrinas dos venenos de B. jararaca. 


\section{2- Estudo comparativo dos processos de autólise de Metaloproteases/desintegrinas (MDs)}

As MDs descritas na literatura apresentam um alto grau de identidade (70\%, em média de acordo com SILVA, 2003) e, no entanto, tem sido observado que as mesmas apresentam diferentes comportamentos em relação ao processo de autólise. Todas MDs sofrem esse processo, que ocasiona a separação e liberação do domínio metaloprotease (catalítico), de massa molecular próxima a $25 \mathrm{kDa}$ e dos domínios tipo-desintegrina e rico em cisteína, uma molécula de massa molecular aproximada de 30kDa.

Com o objetivo de verificar possíveis diferenças no processo de autólise, nós estudamos as MDs alternagina, isolada de veneno de B. alternatus (SOUZA et al., 2000), e a bothropasina, isolada pelo método de Muniz (MUNIZ, 2007). Para que os processos de autólise fossem realizados as duas proteínas foram purificadas até o maior grau de pureza, seguindo etapas de purificação subseqüentes aquelas utilizadas nos estudos descritos no item 4.1 ou através de alterações das metodologias descritas na literatura.

A alternagina, uma SVMPs da classe PIII, foi purificada através de alteração do método padronizado por Souza e colaboradores (SOUZA et al., 2000). O veneno bruto de B. alternatus foi ressuspendido em tampão e aplicado na coluna com resina de troca iônica ANX Sepharose Fast Flow. O perfil cromatográfico e o SDS-PAGE das frações eluídas da coluna estão representados na Figura 4.4. A proteína de massa molecular aproximada de 55kDa foi eluída no intervalo de 0 a $0,3 \mathrm{M}$ de $\mathrm{NaCl}$. As frações que correspondem ao pico mostrado na Figura 4.4 foram reunidas e concentradas até $1 \mathrm{ml}$. Esta solução protéica foi aplicada em coluna com resina de exclusão de tamanho Superdex75. O perfil cromatográfico desta etapa de purificação e o SDSPAGE referente às frações eluídas desta coluna estão representados na figura 4.5. As amostras com maior grau de pureza com a proteína de $55 \mathrm{kDa}$ foram reunidas e congeladas a $-80^{\circ} \mathrm{C}$. 


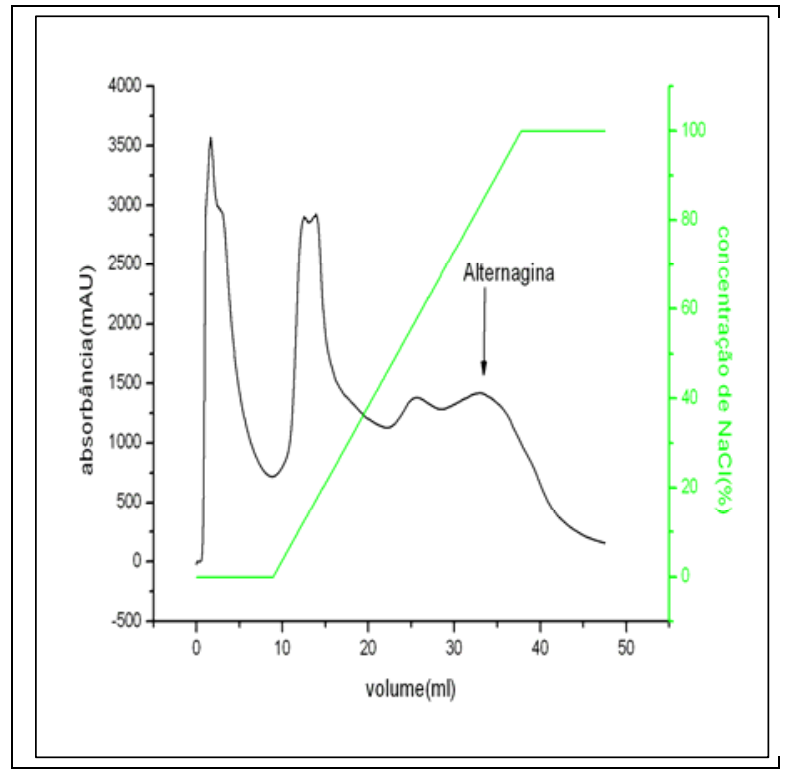

(a)

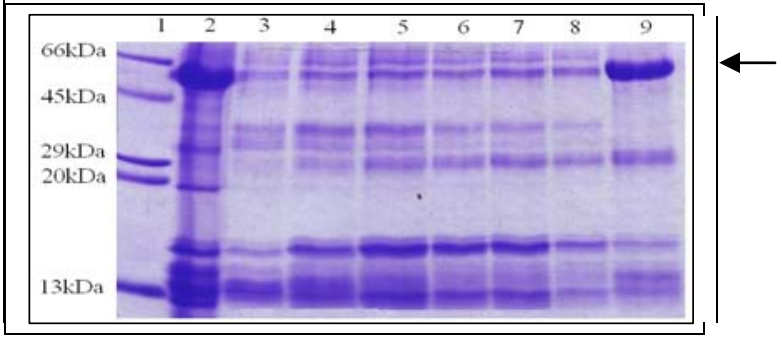

(b)

Figura 4.4: Análise da primeira etapa da purificação da alternagina, partindo de $50 \mathrm{mg}$ de veneno de $B$. alternatus em tampão $10 \mathrm{mM}$ de fosfato de sódio $\mathrm{pH} 7,2$.(a) Perfil cromatográfico da coluna com resina ANX Fast Flow, a linha verde representa o gradiente linear de 0 a $100 \%$ de tampão com $0,3 \mathrm{M}$ de $\mathrm{NaCl}$ (b) SDS-PAGE referente a Fig.4.4(a): coluna 1, padrão de massa molecular; coluna 2, veneno bruto $(50 \mathrm{mg} / \mathrm{ml})$; colunas 3 a 8 , frações eluídas até com $67 \%$ de tampão $0,3 \mathrm{M}$ de $\mathrm{NaCl}$ e coluna 9 , frações eluidas acima de $67 \%$ de tampão com $0,3 \mathrm{M}$ de $\mathrm{NaCl}$. Seta indica a alternagina.

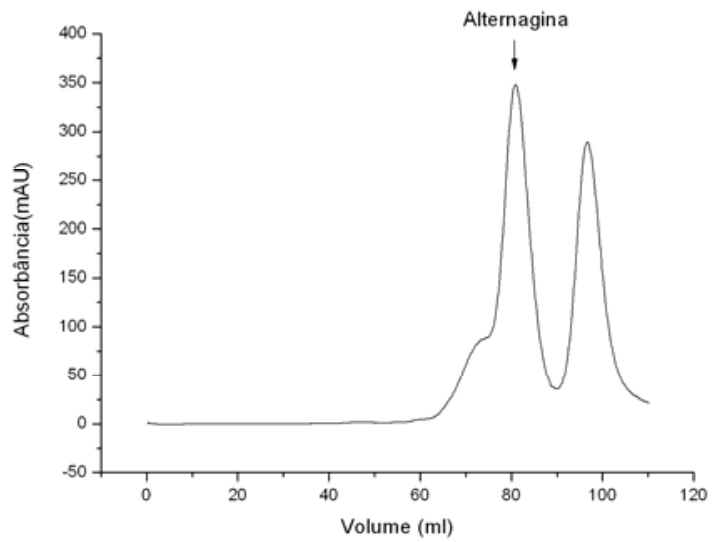

(a)

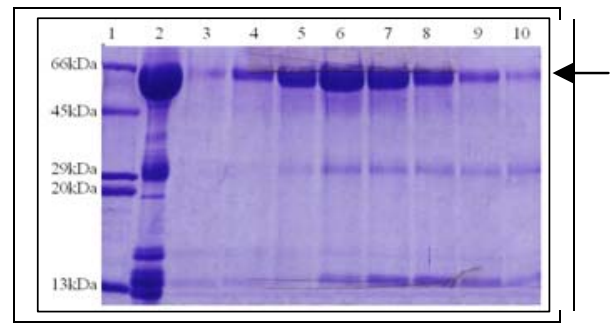

(b)

Figura 4.5: Segunda etapa da purificação da alternagina, amostras que foram eluídas com tampão de 0,3M de $\mathrm{NaCl}$ na ANX Fast Flow; (a) Perfil cromatográfico da Superdex 75; (b)SDS-PAGE referente ao primeiro pico da Fig.4.5(a), coluna 1, padrão de massa molecular, coluna 2, amostra eluída da ANX e colunas 3 a 10, frações do primeiro pico da cromatografia. Seta indica alternagina. 
Para obtenção da bothropsina pura, foi utilizado o método de Muniz (MUNIZ, 2007) com adição de mais uma etapa cromatográfica, para aumentar o grau de pureza. Após aplicação de veneno bruto de B. jararaca em coluna DEAE sepharose, como descrito no item 4.1 e ilustrado na Figura 4.2, as frações eluídas da coluna, contendo proteína de massa molecular aproximada de $55 \mathrm{kDa}$ foram reunidas, concentradas e a solução concentrada foi aplicada em coluna de filtração a gel Superdex75. A figura 4.6 mostra o perfil cromatográfico da coluna Superdex75 e o SDSPAGE das frações eluídas da coluna. As frações com maior grau de pureza da proteína com aproximadamente $55 \mathrm{kDa}$ foram unidas e congeladas a $-80^{\circ} \mathrm{C}$.

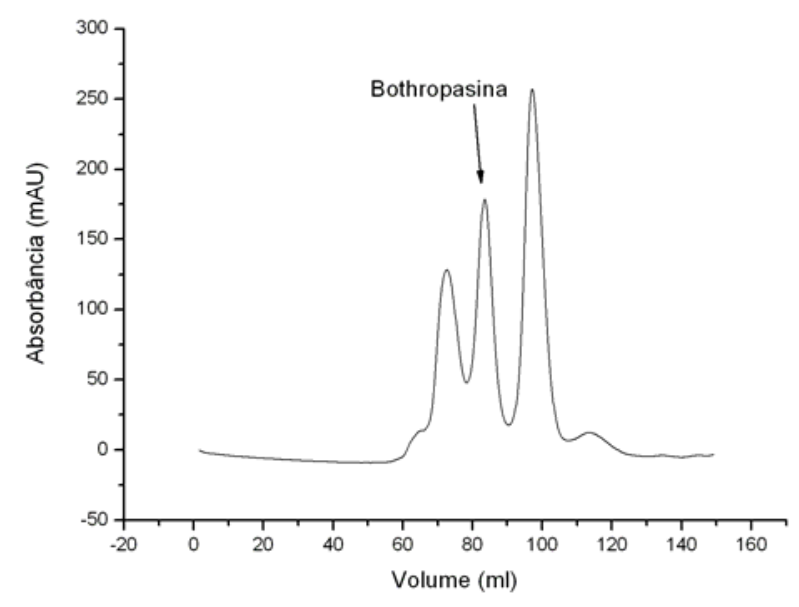

(a)

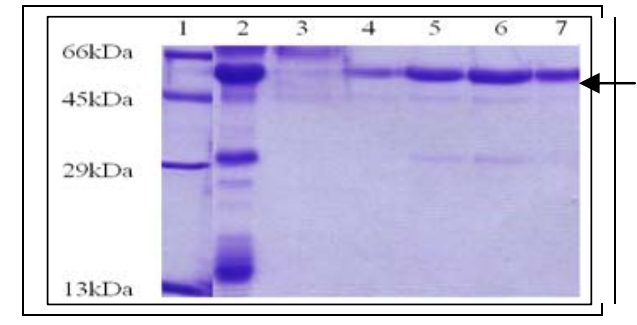

(b)

Figura 4.6: Segunda etapa do processo de purificação da bothropasina pelo método de Muniz (MUNIZ, 2007). (a) Perfil cromatográfico da coluna de exclusão de tamanho, a superdex 75; (b) SDS-PAGE das frações eluídas da coluna: coluna 1, padrão de massa molecular; coluna 2, concentrado das frações do pico da DEAE sepharose que foi eluida com $100 \%$ de $0,5 \mathrm{M}$ de $\mathrm{NaCl}$; coluna 3, fração do primeiro pico da Fig. 4.6; colunas 4 a 7, frações eluídas referentes ao segundo pico do perfil cromatográfico.

O estudo de autólise foi realizado incubando-se as duas proteínas (na mesma concentração), após serem completamente descongeladas, em diferentes temperaturas $\left(25^{\circ} \mathrm{C}\right.$ e $\left.6^{\circ} \mathrm{C}\right)$, retirando-se alíquotas em tempos determinados $(1,6,8,11,24,33,48,72$ e 284 horas $)$ e analisando-as em gel de poliacrilamida. 
Em temperatura ambiente $\left(25^{\circ} \mathrm{C}\right)$, a alternagina (Fig.4.7) apresentou uma alta proteólise produzindo um fragmento polipeptídico de $30 \mathrm{kDa}$, denominado alt-C (SOUZA et al., 2000), e também observamos uma forte banda de $43 \mathrm{kDa}$. A formação de molécula de massa molecular de 43kDa sugere que o processo de autólise para liberação dos domínios DC ocorre em mais de uma etapa (em pelo menos uma parte das moléculas de MD), com a clivagem ocorrendo em dois pontos diferentes da molécula de MD. A molécula de 43kDa deve ser constituída pelos domínios tipo-desintegrina e rico em cisteína ( $\mathrm{DC}$, de $30 \mathrm{kDa}$ ) e uma parte da região C-terminal do domínio catalítico $(13 \mathrm{kDa})$. Com o passar do tempo, o produto de $43 \mathrm{kDa}$ pode também ser processado formando a alt-C, porque foi vista uma diminuição da banda de $43 \mathrm{kDa}$, durante a autólise e aumento da banda de $30 \mathrm{kDa}$. Observamos que o processo de autólise da alternagina a $25^{\circ} \mathrm{C}$ é bastante intenso e que nas primeiras 8 horas aproximadamente $50 \%$ das moléculas da proteína foram processadas em alt-C. Após esse período, a proteína continua sendo processada sendo que após três dias aproximadamente $80 \%$ das moléculas foram processadas a alt-C e o processo aparentemente estabiliza.

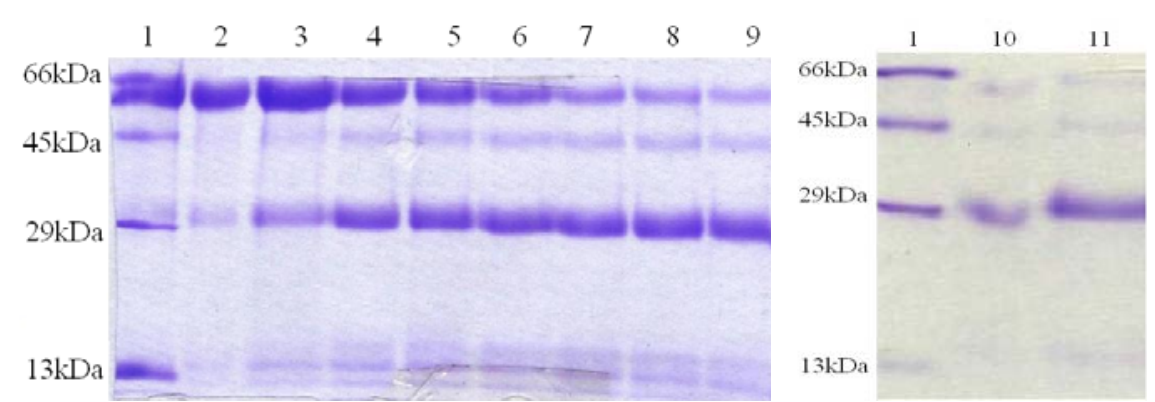

Figura 4.7: Análise em SDS-PAGE da autólise da alternagina a $25^{\circ} \mathrm{C}$. Coluna 1, padrão de massa molecular; coluna 2, processo autólise no tempo 0 ; coluna 3, autólise após uma hora; coluna 4, após 6 horas; coluna 5, após 8 horas; coluna 6, após 11 horas; coluna 7, após 24 horas; coluna 8 , após 33 horas; coluna 9, após 2 dias; coluna 10, após 3 dias; coluna 11, após 11 dias.

À temperatura ambiente, $25^{\circ} \mathrm{C}$, o processo de autólise da bothropasina também produz moléculas de massa molecular de 43 e 30kDa (Fig.4.8), porém, a intensidade desta banda de 
$43 \mathrm{kDa}$ é bem mais fraca que a banda de $43 \mathrm{kDa}$ formada pela autólise da alternagina. Este fato sugere que o processo de formação da molécula de $43 \mathrm{kDa}$ é menos intenso na bothropasina do que na alternagina, e que a autólise ocorre diretamente entre os domínios M (catalítico) e DC (tipo-desintegrina e rico em cisteína). A molécula formada pelos domínios tipo-desintegrina e rico em cisteínas foi chamada por nós de bot-C. Após 8hs, observamos que aparentemente $50 \%$ das moléculas de bothropasina foram processadas, como observado na alternagina. Após 2 dias o processo de autólise parece ficar estável, com aproximadamente $80 \%$ das moléculas de bothropasina sendo reduzida aos domínios DC.

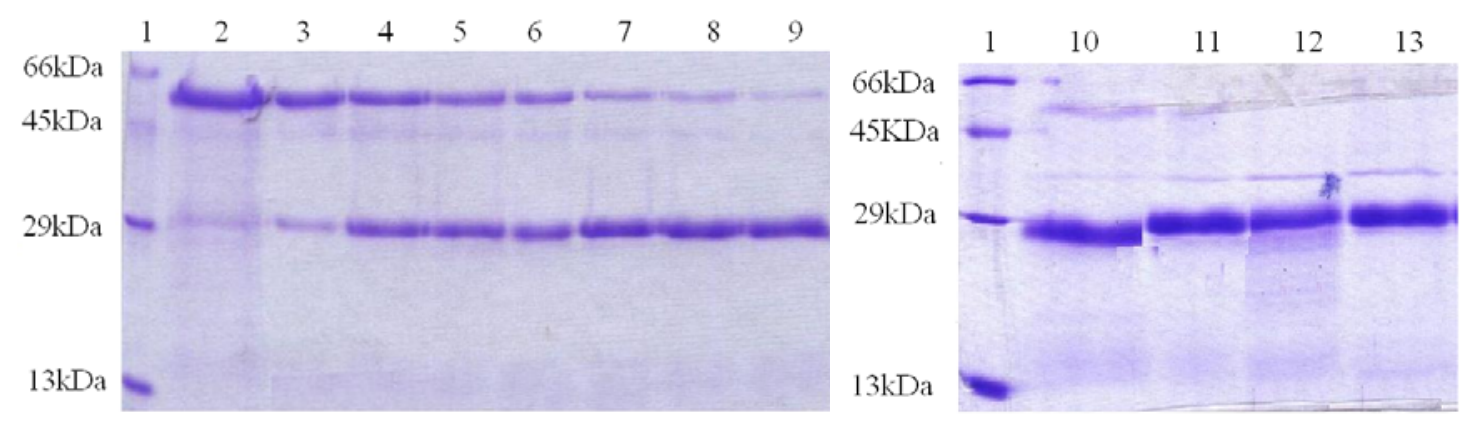

Figura 4.8: Análise em SDS-PAGE da autólise da bothropasina a $25^{\circ} \mathrm{C}$ Coluna 1, o padrão de massa molecular; coluna 2, resultado das purificações tempo 0 de degradação; coluna 3 , autólise após uma hora; coluna 4, após 6 horas; coluna 5, após 8 horas; coluna 6 , após 11 horas; coluna 7, após 24 horas; coluna 8 , após 33 horas; coluna 9, após 2 dias; coluna 10, após 3 dias; coluna 11, após 4 dias; coluna 12, após 7 dias; coluna 13, após 11 dias.

Assim, nossas observações sobre os processos de autólise da alternagina e bothropasina, a $25^{\circ} \mathrm{C}$, são de que no final dos processos as duas proteínas apresentam características semelhantes e que ao final de 11 dias as duas proteínas são praticamente igualmente processadas. No entanto, as duas proteínas apresentam comportamentos diferentes no início do processamento autoproteolítico. A autólise da alternagina se processa com uma proporção elevada da molécula de $43 \mathrm{kDa}$ enquanto que a bothropasina é processada aos domínios DC, sem formar grande quantidade da molécula de $43 \mathrm{kDa}$. 
O processo de autólise de outras proteínas pertencentes a classe das SVMPs PIII tem sido descrito na literatura. Esses estudos mostram que sem a adição de cálcio, proteínas PIII sofrem autólise produzindo uma molécula de massa molecular de 43kDa, que posteriormente libera os domínios DC (massa molecular de $30 \mathrm{kDa}$ ). Este comportamento foi observado para as proteínas brevilysin H6 (H6), uma PIII isolada do veneno da serpente Gloydius halys brevicaudus (FUJIMURA et al., 2000) para catrocolastatina, isolada do veneno de Crotalus atrox. (SHIMOKAWA et al., 1997) e para a jararagina, isolada do veneno de B. jararaca (MOURADA-SILVA et al., 2003). No estudo da H6 os autores mostram, através do seqüenciamento do domínio processado, que a molécula de $43 \mathrm{kDa}$ é formada pela clivagem da ligação Leu ${ }^{98}$-Leu ${ }^{99}$, fato que corrobora a teoria de que a clivagem por metaloproteases ocorre geralmente em aminoácidos de ligações peptídicas adjacentes a resíduos hidrofóbicos, tais como Leu, Ile, Val, Met, Phe, Tyr (FUJIMURA et al., 2000).

A alternagina ainda não teve sua seqüência de aminoácidos determinada, mas a seqüência de resíduos da bothropasina foi determinada pela resolução da estrutura tridimensional da molécula (MUNIZ, 2007). A bothropasina apresenta uma ligação peptídica Leu-Leu (Fig. 4.9), em posição correspondente á ligação Leu ${ }^{98}$-Leu ${ }^{99}$ que é clivada na H6. Esta pode ser a ligação peptídica clivada também nessa proteína, uma vez que a massa molecular do produto formado, 43kDa, é semelhante ao observado para a autólise da H6.

Moura-da-Silva e colaboradores (MOURA-DA-SILVA et al., 2003) estudaram a autólise da jararagina verificando que a ligação clivada na formação da molécula de $43 \mathrm{kDa}$ é a ligação $\mathrm{Arg}^{85}-\mathrm{Lys}^{86}$, formando, portanto, uma molécula de massa molecular um pouco maior do que a formada na autólise da H6. Os autores observaram, também, moléculas de jararagina-C (jara-C) iniciando com as seqüências ISPP (isolada do veneno), IISPP (isolada do veneno) e ISPP 
(produto da autólise da jararagina), $\mathrm{O}$ fato de que a banda a 30kDa, correspondente a molécula jara-C, só aparecer em gel desnaturante mais o fato da presença das três diferentes formas de jaraC deu subsídios para os autores proporem que a jararagina ocorra sob três formas distintas no veneno. Uma das formas seria proteoliticamente instável e seria rapidamente levada a jara-C no veneno. Uma forma não sofreria proteólise in vivo e autólise in vitro e seria, portanto, mantida com massa molecular de 55kDa. Outra forma seria susceptível a clivagem formando a molécula de massa molecular de 43kDa, na qual os domínios DC estariam ligados a uma parte do domínio M através de ligações dissulfeto, o que levaria, portanto, a formação de uma molécula com perfil de pontes dissulfeto diferente do perfil conhecido para SVMPs PIII. As pontes de dissulfeto da catrocolastatina e da bothropasina foram determinadas por clivagem seguida de detecção bioquímica das pontes e por determinação da estrutura tridimensional, respectivamente (CALVETTE et al., 2000; MUNIZ, 2007) e ambas apresentam o mesmo padrão de pontes dissulfeto.

$\mathrm{Na}$ adição de cálcio, a molécula de $43 \mathrm{kDa}$ não é observada nos estudos descritos na literatura para MPs e os autores citam que isto se deve ao fato de que, na adição de íons cálcio a proteína fica mais estável, não sofrendo o processo de autólise. A análise da estrutura tridimensional da bothropasina (MUNIZ, 2007) resultou na observação de três sítios de ligação de íons cálcio. Um dos sítios de ligação de cálcio encontra-se no domínio catalítico e já tem sido descrito na literatura como essencial para a estabilidade deste domínio e, conseqüentemente, para a atividade catalítica do domínio (GOMIS-RUTH et al., 1998). Os outros dois sítios de ligação de íons cálcio encontram-se no domínio tipo-desintegrina, sendo um dos sítios no início do domínio e o outro próximo ao motivo $\mathrm{ECD}$, sendo inclusive estabilizado através de uma ligação do resíduo Glu do motivo ECD com o cálcio. Interessante observação é que a proteína bothropasina 
utilizada para resolução da estrutura não foi tratada com íons cálcio, e, portanto, eles já estavam ligados à molécula no veneno.

Podemos prever que com a adição de íons cálcio leva ao perfeito enovelamento das moléculas e, conseqüentemente, à proteção do sítio de clivagem e a proteína fica mais resistente à autólise. Portanto, se para as mesmas condições experimentais de autólise nós encontramos que a alternagina se processa de forma mais intensa na molécula de massa molecular de $43 \mathrm{kDa}$ do que a bothropasina, podemos sugerir que a molécula de alternagina tenha a região do sítio de clivagem $\left(\operatorname{Leu}^{98}{ }^{- \text {Leu }^{99}}\right)$ mais susceptível a ação proteolítica. Talvez a molécula de alternagina tenha um enovelamento mais "aberto" nessa região, mas não é possível fazer essa afirmativa sem o conhecimento da estrutura da molécula de alternagina.

Nossos estudos de autólise da bothropasina e alternagina foram realizados sem a adição de íons cálcio, e, portanto podemos comparar nossos resultados com os descritos na literatura para outras MPs e particularmente com a jararagina, uma isoforma da bothropasina. Foi demonstrado que a jararagina, após 11 dias de autólise a $25^{\circ} \mathrm{C}$ manteve-se majoritariamente na forma não processada, com uma porcentagem aproximada de 10\% de autólise. A Figura 4.10 mostra os géis de eletroforese do processo de autólise da bothropasina, realizado nesse trabalho, e o processo da jararagina (MOURA-DA-SILVA et al., 2003). No caso da bothropasina e também para alternagina, nós encontramos um comportamento oposto, com a quase totalidade das moléculas sendo processada aos domínios DC (FIGURAS 4.7 e 4.8). Assim, embora a alternagina e bothropasina tenham comportamentos diferentes no início da autólise, ambas são majoritariamente processadas proteoliticamente à molécula de massa molecular de $30 \mathrm{kDa}$ correspondente aos domínios DC, enquanto que a jararagina permanece majoritariamente sem sofrer processamento. 
Seqüência de aminoácidos da Bothropasina:

EQQKYNPFRYVELFIVVDQGMVTKNNGDLDKIKARMYELANIVNEILRYLYMHAALVG

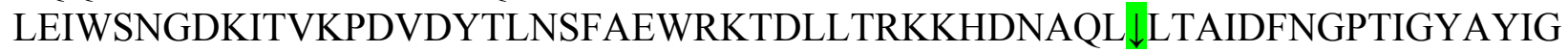
SMCHPKRSVAIVEDYSPINLVVAVIMAHEMGHNLGIHHDTDFCSCGDYPCIMGPTISNEP SKFFSNCSYIQCWDFIMKENPQCILNEPLGT $\downarrow D I V S P P V C G N E L L E V G E E C D C G T P E N C Q N$ ECCDAATCKLKSGSQCGHGDCCEQCKFSKSGTECRASMSECDPAEHCTGQSSECPADVF HKNGQPCLDNYGYCYNGNCPIMYHQCYALFGADVYEAEDSCFKDNQKGNYYGYCRKE NGKKIPCAPEDVKCGRLYCKDNSPGQNNPCKMFYSNDDEHKGMVLPGTKCADGKVCS NGHCVDVATAY.

Figura 4.9 - Seqüência de aminoácidos da bothropasina, mostrando os sítios de autólise para formaçâo das moléculas de $43 \mathrm{kDa}$ (primeira seta em verde) e $30 \mathrm{kDa}$ (segunda seta verde).

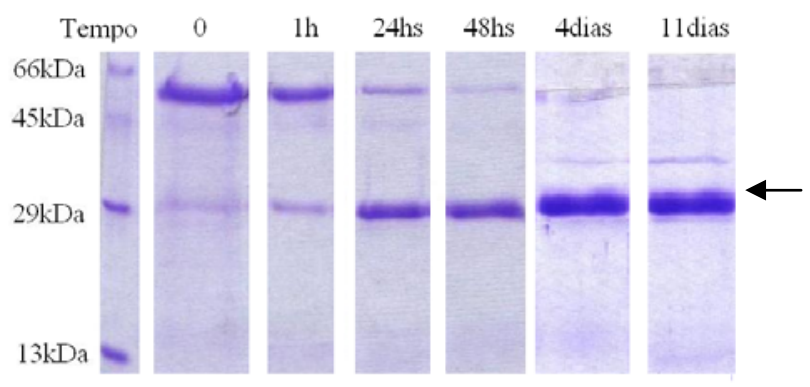

(a)

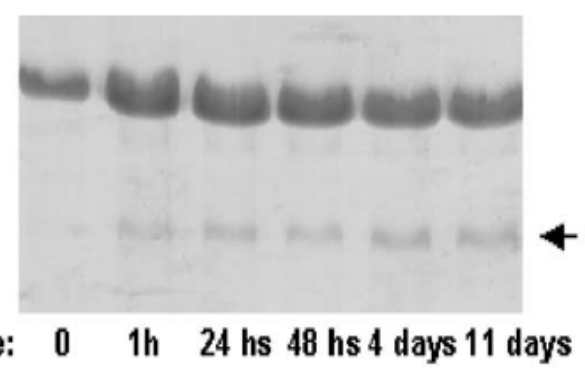

(b)

Figura 4.10 - Análise comparativa do processo de autólise das MDs de B.jararaca:(a) bothropasina (feita nesse trabalho), (b) jararagina (MOURA-DA-SILVA et al., 2003); em SDSPAGE. As setas indicam o produto de $30 \mathrm{kDa}$ da autólise.

À temperatura de $6^{\circ} \mathrm{C}$, verificamos, através da análise das amostras em gel de poliacrilamida (Figuras 4.11 e 4.12), que as diferenças entre os produtos formados para a autólise da alternagina e a bothropasina são menores do que a $25^{\circ} \mathrm{C}$. A autólise da alternagina (Fig. 4.11) produz uma molécula de massa molecular de $43 \mathrm{kDa}$, assim como a $25^{\circ} \mathrm{C}$, porém a intensidade da banda observada no gel é mais fraca. Após 3 dias, o processo não tem continuidade e aproximadamente $50 \%$ da alternagina é reduzida a alt-C. Portanto, o abaixamento da temperatura de $25^{\circ} \mathrm{C}$ para $6^{\circ} \mathrm{C}$ inibiu o processo de autólise em aproximadamente $50 \%$. 


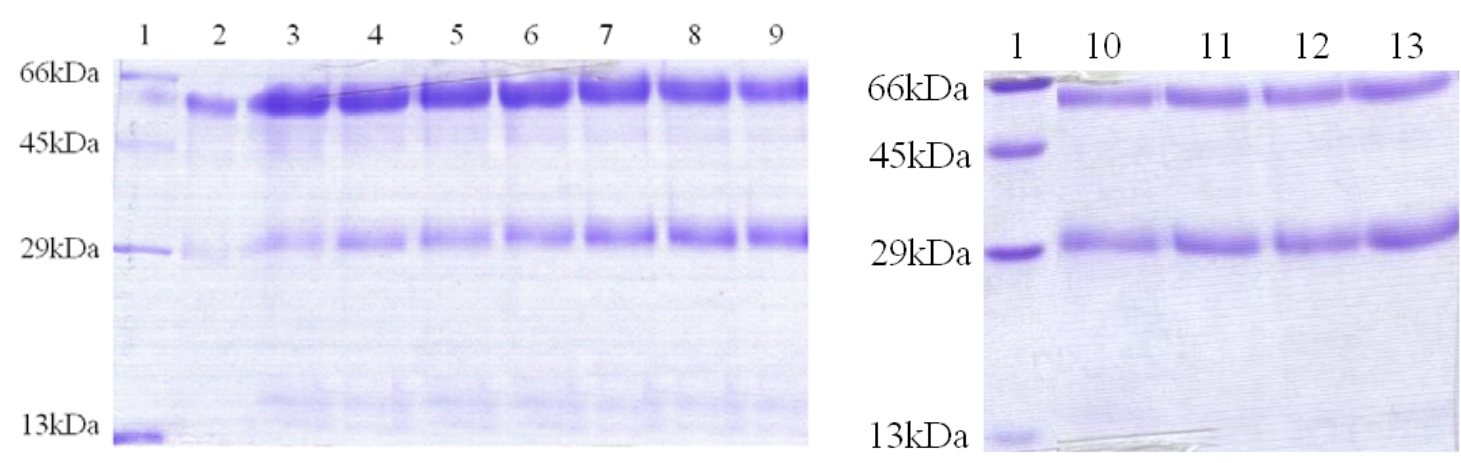

Figura 4.11: Análise em SDS-PAGE da autólise da alternagina em temperatura de $6^{\circ} \mathrm{C}$. Coluna 1, padrão de massa molecular; coluna 2, resultado das purificações tempo 0 de degradação; coluna 3, autólise após uma hora; coluna 4, após 6 horas; coluna 5, após 8 horas; coluna 6, após 11 horas; coluna 7, após 24 horas; coluna 8, após 33 horas; coluna 9, após 2 dias; coluna 10, após 3 dias; coluna 11, após 4 dias; coluna 12, após 7 dias; coluna 13, após 11 dias.

Para o processo de autólise da bothropasina a $6{ }^{\circ} \mathrm{C}$ (Fig. 4.12), observamos um comportamento semelhante ao observado no processo a $25^{\circ} \mathrm{C}$, com pouca formação da molécula de $43 \mathrm{kDa}$. Assim como observado para a alternagina, a partir de 3 dias o processo aparentemente termina e aproximadamente $50 \%$ das moléculas foram processadas aos domínios DC.

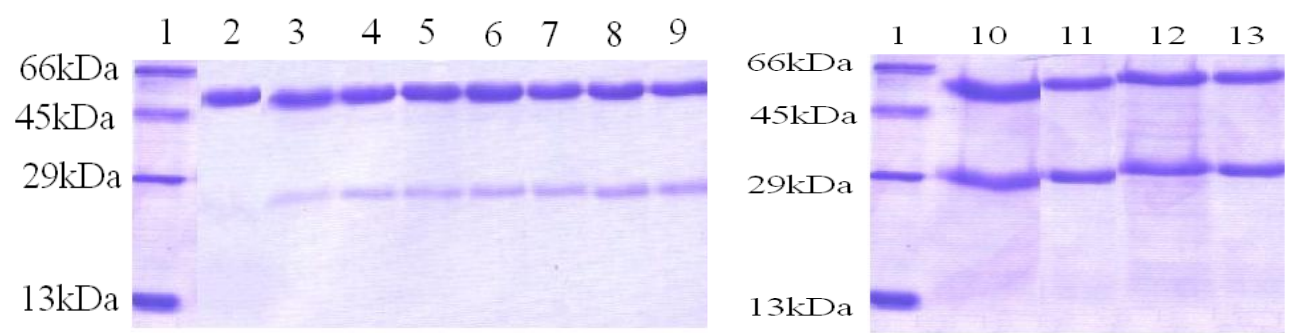

Figura 4.12: Análise em SDS-PAGE da autólise da bothropasina em temperatura de $6^{\circ} \mathrm{C}$. Coluna 1, padrão de massa molecular; coluna 2, resultado das purificações tempo 0 de degradação; coluna 3, autólise após uma hora; coluna 4, após 6 horas; coluna 5, após 8 horas; coluna 6, após 11 horas; coluna 7, após 24 horas; coluna 8, após 33 horas; coluna 9, após 2 dias; coluna 10, após 3 dias; coluna 11, após 4 dias; coluna 12, após 7 dias; coluna 13, após 11 dias.

Portanto, o processo de autólise das proteínas alternagina e bothropasina é dependente da temperatura, sendo diminuido a temperatura de $6^{\circ} \mathrm{C}$, fazendo que ao final de 11 dias somente $50 \%$ das moléculas dessas proteínas sejam processadas, enquanto que a $25^{\circ} \mathrm{C}$ nesse mesmo 
período de tempo aproximadamente $80 \%$ das moléculas sejam processadas. Isso se deve, provavelmente, porque com o abaixamento da temperatura o movimento das moléculas é menor o que não favorece o ataque proteolítico.

As metaloproteases/desintegrinas processadas foram analisadas através de reação de immunobloting utilizando o anticorpo anti-alt-C, que foi obtido com a injeção de alt-C em camundongos (Souza et al., 2000). A Figura 4.13 mostra os resultados obtidos na reação de immunobloting para as proteínas isoladas com os métodos de Mandelbaum (MANDELBAUN et al., 1982) e Muniz (MUNIZ, 2007).

Analisando a membrana de imunoblotting vemos que os produtos da autólise tanto de $30 \mathrm{kDa}$, como de $45 \mathrm{kDa}$ reagem ao anticorpo de alt-C. A partir dessa informação, podemos afirmar que o produto de $30 \mathrm{kDa}$ são os domínios tipo-desintegrina e rico em cisteína e que o produto de $45 \mathrm{kDa}$ apresenta esses dois domínios mais uma parte do domínio metaloprotease.

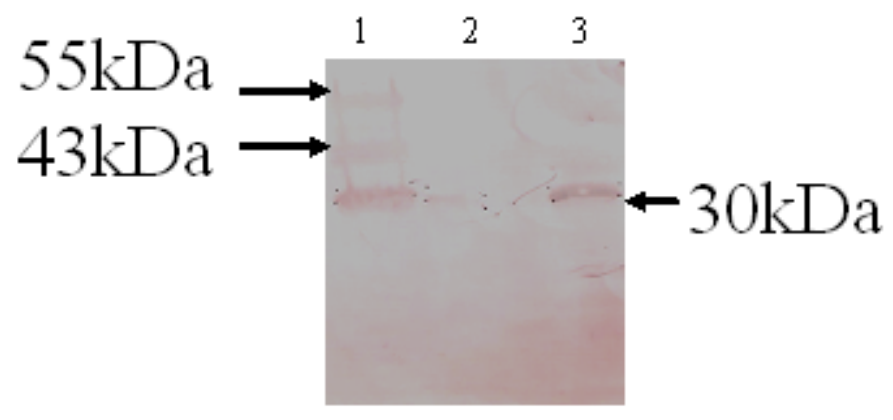

Figura 4.13: Análise dos produtos da autólise das metaloproteianses/desintegrinas por imunoblotting. Coluna 1: autólise da proteína purificada pelo método de Mandelbaum (MANDELBAUN et al., 1982), colunas 2 e 3: autólise da proteína purificada pelo método de Muniz (MUNIZ, 2007) 


\section{3-Estudos do desenovelamento das proteínas alternagina e da bothropasina através das técnicas de Espectroscopia de Dicroísmo Circular e Fluorescência}

Até 2006 não havia nenhuma estrutura de proteínas da classe PIII das SVMP's depositada no PDB (Protein Data Bank) e poucas eram as informações sobre as estruturas dos diferentes domínios das moléculas e suas relações. Recentemente, com a determinação de algumas estruturas cristalográficas desta classe de proteínas (TAKEDA et al., 2006; IGARASHI et al., 2007; MUNIZ, 2007) algumas questões começaram a ser elucidadas. No entanto, ainda restam muitas dúvidas de como os domínios interagem entre si e como os mesmos estão envolvidos nas atividades biológicas dessas proteínas.

Os diferentes resultados obtidos nos estudos de autólise da alternagina e bothropasina levaram ao questionamento sobre a estabilidade das duas proteínas. Embora sejam isoladas de fontes diferentes, a duas proteínas apresentam identidade seqüencial elevada $(90 \%)$ e como mostrado no item 4.2 apresentam comportamentos diferentes frente ao processo de autólise. Assim, os estudos da estrutura secundária e terciária dessas moléculas podem levar a informações relevantes que auxiliem no entendimento desta questão.

Assim, o objetivo deste estudo foi analisar o comportamento de desenovelamento frente a agentes químicos das duas MDs, bothropasina e alternagina, a fim de verificar se há alguma correlação ou diferença entre os mesmos. Para isso, foram utilizadas duas técnicas diferentes, espectroscopia de dicroísmo circular e espectroscopia de fluorescência, que podem ser úteis no estudo da estabilidade estrutural de proteínas e de seus domínios. Os estudos de dicroísmo circular foram usados para analisar a estrutura secundária da alternagina e da bothropasina (isolada seguindo o método de Muniz (MUNIZ, 2007). As duas proteínas estavam solubilizadas nas mesmas soluções tampões $(20 \mathrm{mM}$ de Tris $\mathrm{pH} 8,0$ e $20 \mathrm{mM}$ de $\mathrm{NaCl})$ e foram testadas em 
diferentes concentrações $(0$ a $7 \mathrm{M})$ do agente desnaturante (Hidrocloreto de Guanidina, Gnd$\mathrm{HCl}$ ). Analisando as curvas de desnaturação química (Fig. 4.14) obtidos para as duas proteínas observamos que o comportamento das duas frente ao agente desnaturante são semelhantes.

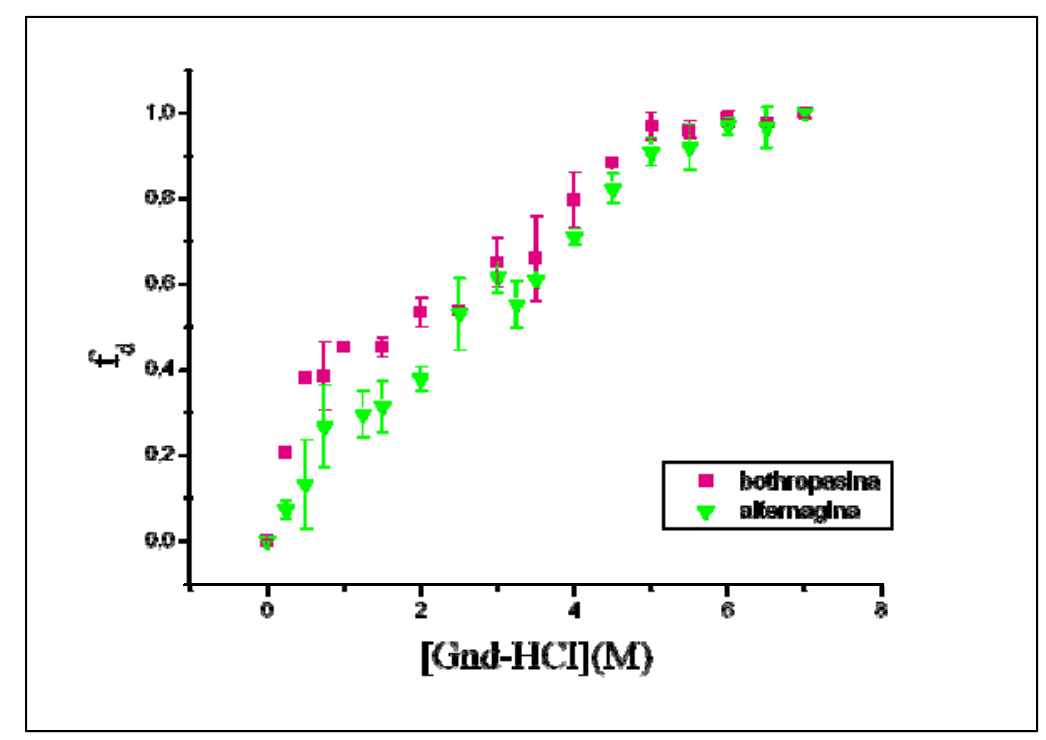

Figura 4.14: Curva de desnaturação química por hidrocloreto de guanidina (Gnd-HCl), monitoradas por dicró́smo circular, das proteínas bothropasina e a alternagina, no comprimento de onda de $220 \mathrm{~nm}$ : fração de proteína desnaturada $\left(f_{d}\right)$ em função da concentração de $\mathrm{Gnd}-\mathrm{HCl}(\mathrm{M})$.

Para uma melhor análise dos domínios, foram realizadas as mesmas medidas com a alt-C, o domínio processado DC da alternagina. A alt-C foi purificada usando o protocolo de Souza (SOUZA ET AL., 2000). Na alt-C só ocorre o início da desnaturação química significativa na curva a partir de $2 \mathrm{M}$ de Hidrocloreto de guanidina, enquanto que na alternagina ocorre variação nas concentrações iniciais de hidrocloreto de guanidina. Ao analisarmos e compararmos as curvas de desnaturação química da alternagina e alt-C (Fig. 4.15 e 4.17), podemos inferir que a variação da fração de desnaturação $(f d)$ observada no intervalo de 0 a $2 \mathrm{M}$ do agente desnaturante na curva obtida para a alternagina é resultante da desnaturação química do domínio metaloprotease. $\mathrm{O}$ comportamento da alt-C nessa região é diferente do obtido para alternagina, e uma vez que a única diferença entre as moléculas é a presença do domínio metaloprotease na alternagina, 
podemos propor que essa diferença seja devido à desnaturação do domínio metaloprotease. A partir de $2 \mathrm{M}$ de Hidrocloreto de guanidina o comportamento entre alternagina e alt-C é bastante semelhante.

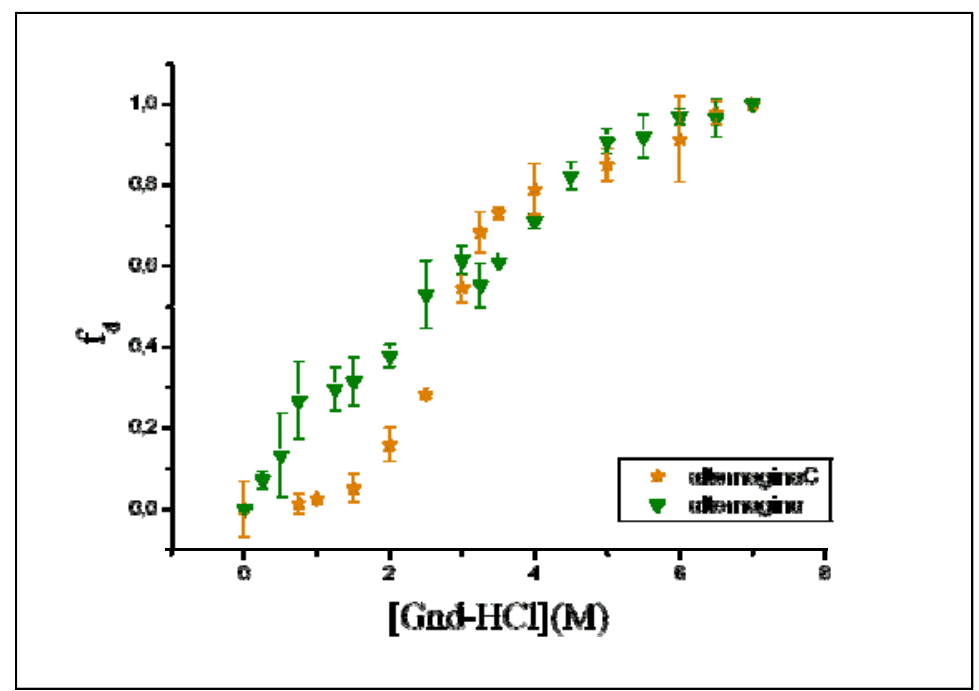

Figura 4.15: Curva de desnaturação química por cloreto de guanidina, monitoradas por dicroísmo circular, no comprimento de onda $220 \mathrm{~nm}$, das proteínas alternagina e a alt-C: fração de proteína desnaturada $\left(\mathrm{f}_{\mathrm{d}}\right)$ em função da concentração de Gnd-HCl(M).

Na comparação das curvas de desnaturação, analisadas por dicroísmo circular, da bothropasina e da bot-C (Fig. 4.16) foi observado um comportamento semelhante ao observado anteriormente para alternagina e alt-C. Nesse e no outro caso aparentemente o domínio metaloprotease sofre o processo de desnaturação até a concentração de $2 \mathrm{M}$ de hidrocloreto de guanidina. 


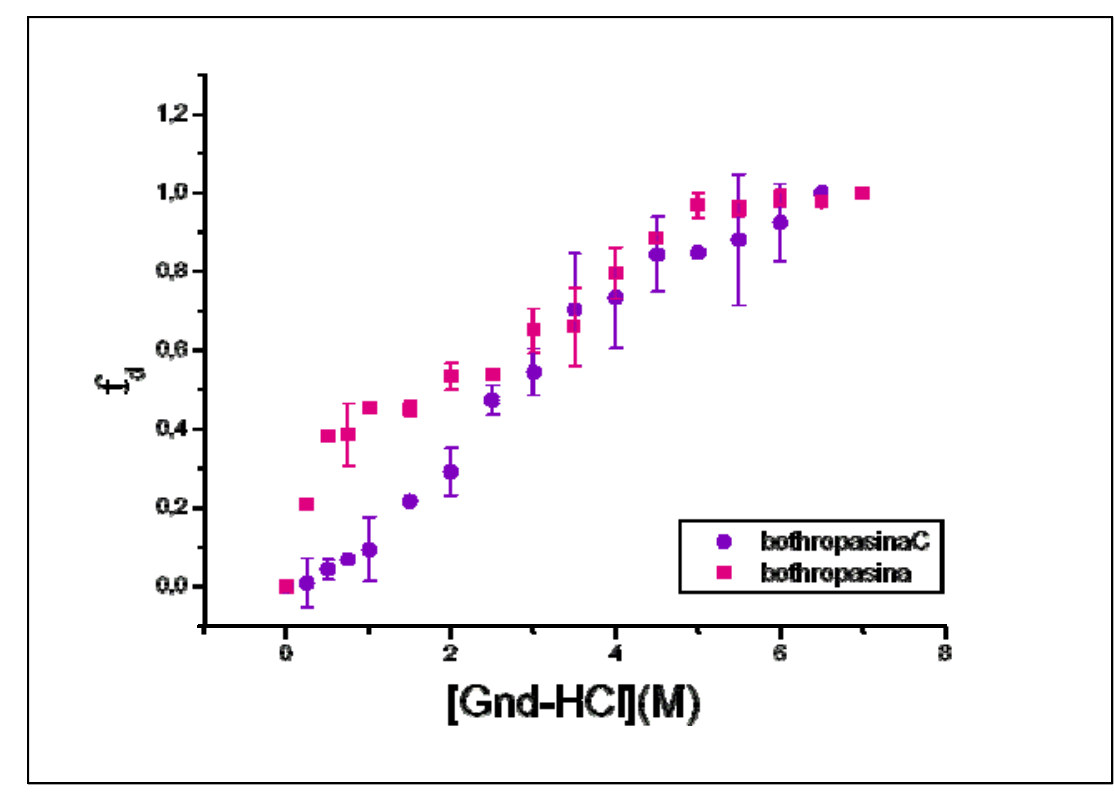

Figura 4.16: Curva de desnaturação química por hidrocloreto de guanidina, monitoradas por dicroísmo circular, no comprimento de onda $220 \mathrm{~nm}$, das proteínas bothropasina e a bot-C: fração de proteína desnaturada $\left(\mathrm{f}_{\mathrm{d}}\right)$ em função da concentração de $\mathrm{Gnd}-\mathrm{HCl}(\mathrm{M})$.

A bot-C possui dois domínios: desintegrina e o rico em cisteína. Pela estrutura da Bothropasina (Fig.1.3), vimos a presença de um grande número de pontes dissulfeto, sete no domínio desintegrina e seis no domínio rico em cisteína, além de uma ponte entre esses dois domínios. Portanto, a região correspondente aos domínios desintegrina e rico em cisteínas são mais estáveis estruturalmente que o domínio metaloprotease, que apresenta apenas três pontes dissulfeto. Assim, os domínios DC apresentam uma maior estabilidade estrutural frente à desnaturação química por hidrocloreto de guanidina, sofrendo modificações na estrutura secundária somente a partir de $2 \mathrm{M}$ de hidrocloreto de guanidina. É interessante observar que, embora o domínio tipo-desintegrina apresente baixo conteúdo de estrutura secundária regular, a estabilidade é alcançada pelo alto número de pontes dissulfeto que existem nos domínios.

A bothropasina possui os três domínios: metaloprotease, tipo-desintegrina e rico em cisteína. Pela análise da estabilidade da estrutura secundária (Figura 4.16), vemos que o domínio metaloprotease é mais suscetível à ação do desnaturante (hidrocloreto de guanidina), o que se 
deve provavelmente a presença de poucas pontes dissulfeto (apenas três). Esse domínio apresenta um maior conteúdo de estrutura secundária regular. No espectro de dicroísmo circular da proteína inteira, isto é, constituída pelos três domínios MDC, é possível observar um espectro característico de polipeptídeos com uma mistura de elementos de estutura secundária ( $\alpha$-hélice, folhas beta e desordenado) (Fig.4.17). Esse comportamento não é encontrado no espectro da altC, o que já era esperado, uma vez que esses domínios carecem de estruturas secundárias regulares.

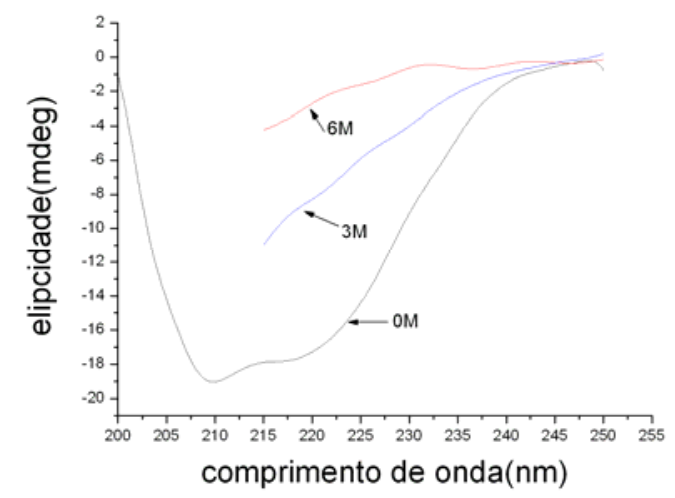

(a)

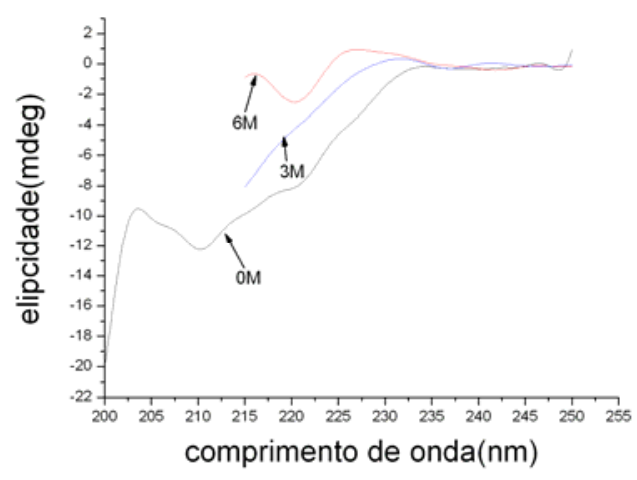

(b)

Figura 4.17 - Espectro de dicroísmo circular, elipcidade em função do comprimento de onda, das proteínas: (a) alternagina , (b) alt-C, sem a presença de agente desnaturante, com $3 \mathrm{M}$ e $6 \mathrm{M}$ de hidrocloreto de guanidina.

A seqüência da alternagina completa não é conhecida, porém os domínios tipodesintegrina e rico em cisteina (alt-C) foram seqüenciados, por degradação de Edman. Análise comparativa das seqüências da alt-C e bot-C mostra que ambas possuem um alto grau de identidade (aproximadamente 90\%). Os domínios metaloprotease dessas proteínas apresentam alta identidade, podemos inferir que a estrutura da alternagina deve ser muito parecida com a da bothropasina. As curvas de desnaturação, monitoradas pelo dicroísmo circular, da bothropasina e 
da alternagina (Fig. 4.14) são muito parecidas, o que sugere um alto grau de semelhança da estabilidade da estrutura secundária.

A técnica de espectroscopia de fluorescência foi utilizada para acompanhar processos de desnaturação química das proteínas em estudo. Os domínios metaloproteases das proteínas alternagina e bothropasina possuem três triptofanos enquanto não há nenhum desse resíduo nos domínios DC. Assim, a técnica de espectroscopia de fluorescência intrínseca foi utilizada para acompanhar o processo de desnaturação das proteínas nas mesmas condições utilizadas nos estudos de dicroísmo circular. As medidas de fluorescência foram feitas com as mesmas amostras usadas nas medidas de dicroísmo circular com as proteínas alternagina e bothropasina. Os espectros de emissão de fluorescência medidos, com excitação em 295 nm (Fig. 4.19), têm como fluoróforo dominante o grupo indol do triptofano e o espectro com excitação em $280 \mathrm{~nm}$ (Fig. 4.18) têm como principal fluoróforo a tirosina e também do triptofano durante o processo de desnaturação. A partir dos espectros de fluorescência, monitorando o centro de massa desses espectros e normalizando estes dados, resultou na curva de desnaturação. Analisando as curvas de desnaturação, obtidas pela técnica de fluorescência, com excitação de $280 \mathrm{~nm}$ e $295 \mathrm{~nm}$ obtidos para a alternagina, observamos que esses são bastante similares (Fig.4.20), mostrando que os triptofanos (3, no domínio $\mathrm{M})$ da molécula se expõem ao solvente nas diversas concentrações de hidrocloreto de guanidina (até próximo a 5M), o que "mascara" a emissão das tirosinas(23 em toda a proteína). Essa exposição gradual dos triptofanos propõe que a desnaturação química do domínio metaloprotease ocorre até $5 \mathrm{M}$ de agente desnaturante. Este comportamento é visualizado na Figura 4.21, onde são comparadas as curvas de desnaturação químicas medidas por fluorescência (280 e $295 \mathrm{~nm}$ ) e dicroísmo circular da alternagina: todas as curvas são similares e 
mostram que modificações ocorrem somente em altas concentrações de hidrocloreto guanidina (Gnd-HCl).

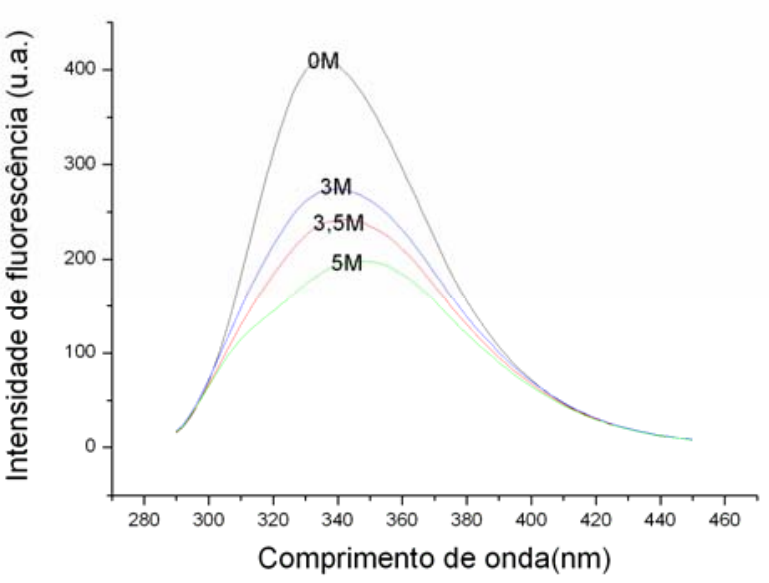

(a)

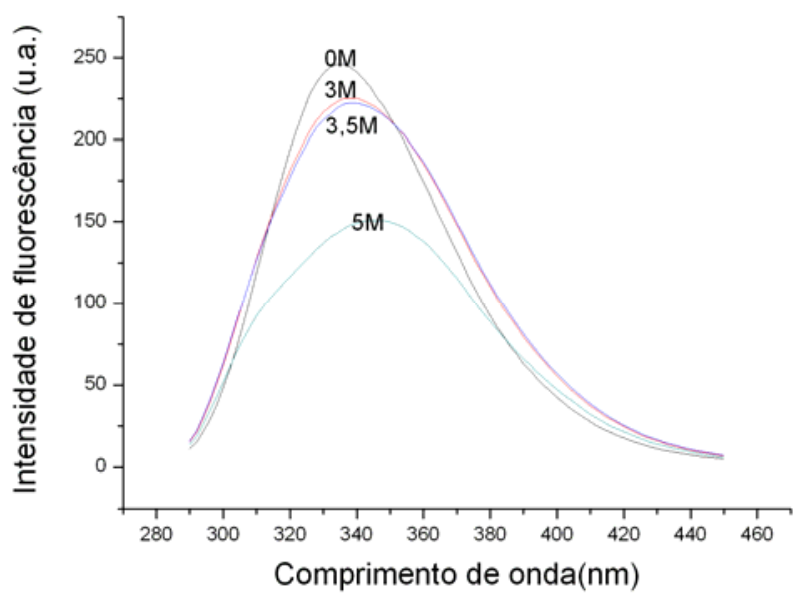

(b)

Fig.4.18 - Espectros de fluorescência, com excitação a 280nm, em diferentes concentrações de agente desnaturantes, hidrocloreto de guanidina, das proteínas : a)alternagina e b)bothropasina

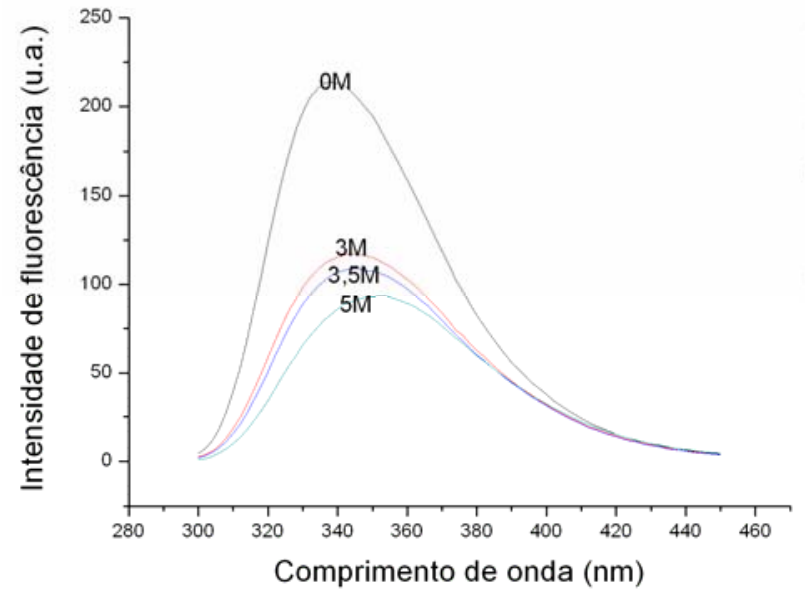

(a)

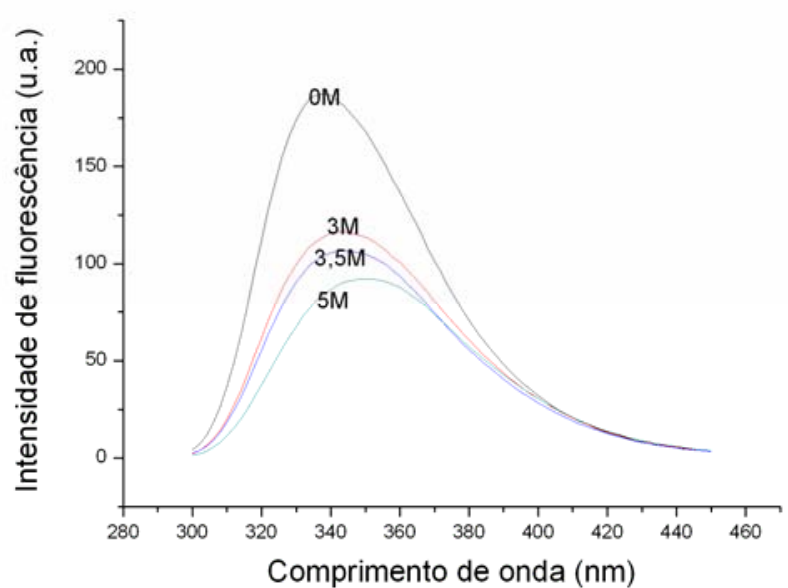

(b)

Fig. 4.19 - Espectros de fluorescência, com excitação a 295nm, em diferentes concentrações de agente desnaturantes, hidrocloreto de guanidina, das proteínas:a)alternagina e b)bothropasina 
A análise comparativa das curvas de desnaturação química, analisada por fluorescência em excitação de $280 \mathrm{~nm}$ e $295 \mathrm{~nm}$ da alternagina e bothropasina (Figura 4.22) mostra que as duas proteínas apresentam comportamento bastante semelhante em relação à exposição dos resíduos de triptofano ao meio no processo de desnaturação. A partir dos resultados, foi visto que a desnaturação química da estrutura terciária (visto nas medidas de fluorescência com excitação de 280 e $295 \mathrm{~nm}$ ) e da estrutura secundária (medidas de dicroismo circular) são semelhantes, o que era esperado.

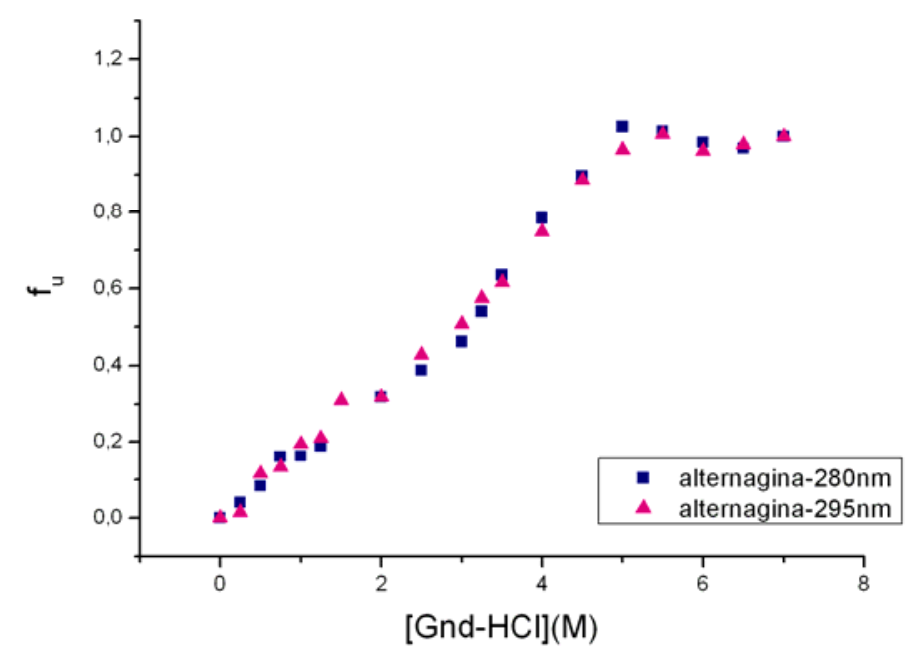

Figura 4.20 - Comparação entre as emissões de fluorescência com excitação de $280 \mathrm{~nm}$ e $295 \mathrm{~nm}$ da alternagina. A desnaturação foi monitorada através do centro de massa, expressa em fração de proteínas desnaturada $\left(f_{u}\right)$, em função da concentração de hidrocloreto de guanidina. 


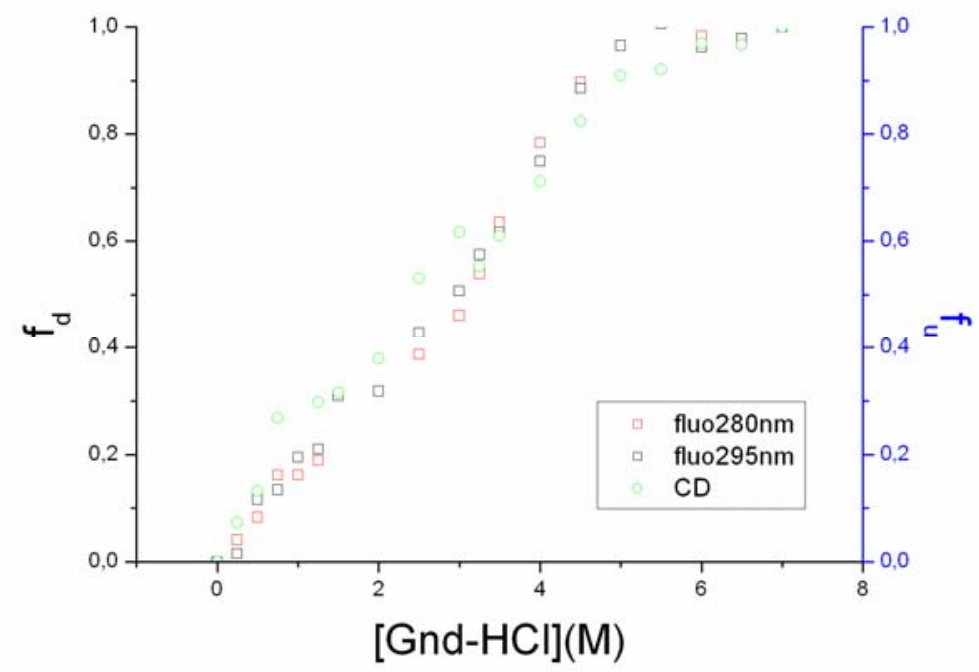

Figura 4.21 - Comparação entre curvas de desnaturação medidas por fluorescência (excitação a $280 \mathrm{~nm}$ e $295 \mathrm{~nm}$ ) e por dicroísmo circular da alternagina. A desnaturação foi monitorada através do centro de massa, expressa em fração de proteínas desnaturada $\left(f_{u}\right)$, em função da concentração de hidrocloreto de guanidina.

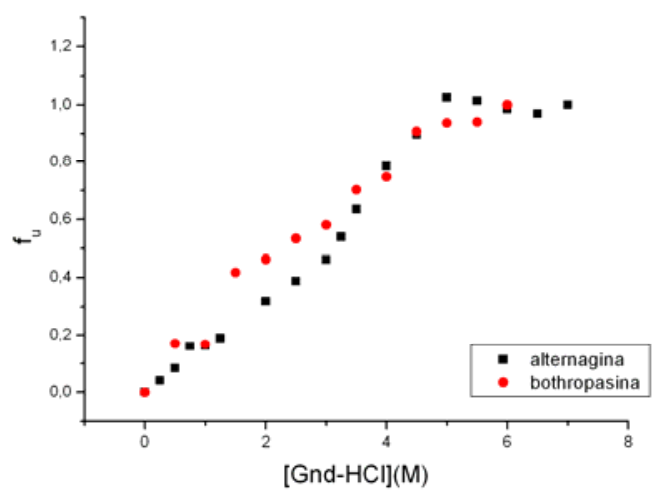

(a)

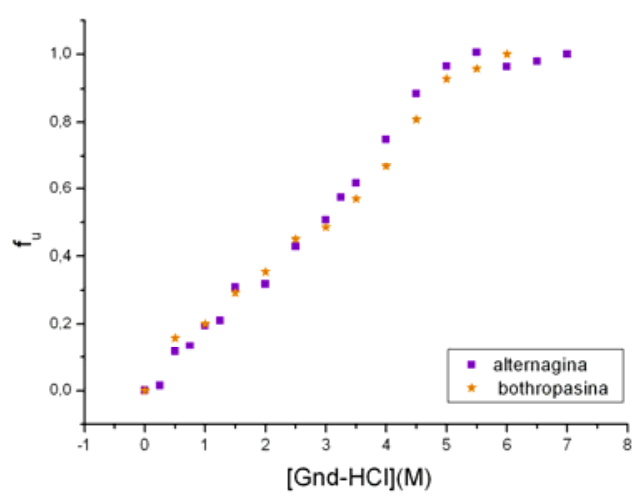

(b)

Figura 4.22. Curvas de desnaturação, monitoradas pela fluorescência, da alternagina e bothropasina em diferentes concentrações de $\mathrm{Gnd}-\mathrm{HCl}$ com excitação de 280nm (a) e a 295nm

(b). A desnaturação foi monitorada através do centro de massa, expressa em fração de proteínas desnaturada $\left(f_{u}\right)$, em função da concentração de hidrocloreto de guanidina.

Portanto, os resultados obtidos de dicroísmo circular e fluorescência das proteínas alternagina e bothropasina sugerem que, a despeito do domínio metaloprotease sofrer 
desnaturação em concentrações bem mais baixas de agente desnaturante que o domínio DC, os resíduos de triptofano que se encontram no domínio $M$ são totalmente expostos ao solvente somente em altas concentrações $(5 \mathrm{M})$ do agente desnaturante. 


\section{Capítulo 5 - Conclusões}

Neste trabalho foram realizados estudos das metaloproteases/desintegrinas (MDCs) isoladas de venenos de serpentes. A presença de isoformas nos venenos, e conseqüentemente a falta de homogeneidade, é um fato conhecido na literatura e tem sido descrito como um dos responsáveis pelas dificuldades encontradas em alguns estudos, como por exemplo na cristalização das proteínas. Observamos que os pesquisadores que estudam proteínas oriundas dos venenos desenvolvem metodologias para o isolamento das moléculas sem levar em conta, na maioria das vezes, que no final do processo as proteínas muito provavelmente não estarão de forma homogênea, principalmente por causa das propriedades físico-químicas semelhantes entre as moléculas de isoformas. Um dos aspectos estudados no presente trabalho foi a análise/identificação das proteínas obtidas através dos métodos descritos na literatura para MDCs isoladas de veneno de B. jararaca. Duas isoformas têm sido descritas para MDCs de B. jararaca, a jararagina e a bothropasina. Foi detectado no nosso Laboratório que a metodologia utilizada para isolamento de jararagina resultou na purificação da bothropasina. Assim, nós usamos dois métodos descritos para isolamento de bothropasina e o método mais utilizado na literatura para isolamento da jararagina. As amostras obtidas nos diferentes métodos seriam analisadas através da técnica de espectrometria de massas, pois a técnica mais acessível, o sequenciamento da região N-terminal das proteínas, não poderia ser utilizado uma vez que essas proteínas apresentam o N-terminal bloqueado. No entanto, devido a problemas no equipamento (espectrômetro de massas) do nosso colaborador, o Prof. Dr. José César Rosa, USP-Ribeirão Preto, as análises ainda não puderam ser realizadas. Uma vez que as MDCs sofrem 
processamento, liberando os domínios metoprotease (M) e tipo-desintegrina e rico em cisteína (DC) as amostras de MDCs obtidas nos três diferentes protocolos foram levadas a autólise e os domínios DC serão analisados por sequenciamento da região N-terminal.

A outra abordagem utilizada nesse trabalho, foi o estudo do processamento autolítico das MDCs alternagina, isolada do veneno de B. alternatus, e da bothropasina, isolada do veneno de B. jararaca. Nós observamos que as duas proteínas, embora tenham alta identidade seqüencial sofrem o processo autoproteolítico de maneiras diferentes. Os produtos da autólise das MDCs são os domínios M (de aproximadamente $25 \mathrm{kDa}$ ) e DC (de aproximadamente $30 \mathrm{kDa}$ ). Os estudos foram realizados em duas temperaturas diferentes, $25^{\circ} \mathrm{C}$ e $6^{\circ} \mathrm{C}$. Observamos que a $25^{\circ} \mathrm{C}$ as duas proteínas, alternagina e bothropasina, apresentam o mesmo comportamento e aproximadamente $80 \%$ das moléculas são processadas ao domínio DC ao final dos onze dias de autólise. No entanto, observamos que nessa temperatura o processo de autólise da alternagina passa pela formação do intermediário de $43 \mathrm{kDa}$ (que seria a o domínio $\mathrm{DC}$ unido a região C-terminal do domínio M) de uma maneira muito mais acentuada do que a bothropasina. Com o passar do tempo, o intermediário de $43 \mathrm{kDa}$ também é processado aos domínios DC. Esse resultado sugere que as proteínas alternagina e bothropasina possam ter regiões de clivagem mais e menos expostas, respectivamente. Comparando os resultados obtidos para as isoformas bothropasina (este trabalho) e jararagina (MOURA-DA-SILVA et al., 2003) a $25^{\circ} \mathrm{C}$ verificamos uma importante diferença no processamento, sendo que a jararagina ao final de 11 dias tem somente aproximadamente $20 \%$ das moléculas processadas enquanto que a bothropasina tem, aproximadamente, $80 \%$ das moléculas processadas. À temperatura de $6^{\circ} \mathrm{C}$ os mesmos comportamentos de formação do intermediário de $43 \mathrm{kDa}$ foram observados, no entanto, o 
processo é menos intenso e ao final de 11 dias somente cerca de $50 \%$ das moléculas de alternagina e bothropasina sofrem o processamento autoproteolítico.

A observação de que as MDCs estudadas, alternagina e bothropasina, tinham diferentes comportamentos sob o ponto de vista de autólise levou aos estudos de desnaturação das proteínas com acompanhamento com a técnica de espectroscopia de dicroísmo circular. A proteína alt-C, o domínio processado DC da alternagina, foi também estudadas. Através desses estudos, foi observado que o domínio metaloprotease é o mais instável apesar de apresentar estrutura secundária mais organizada. Os domínios tipo-desintegrina e o rico em cisteína não são atingidos pela autólise e só começam a sofrer modificações químicas na presença de $2 \mathrm{M}$ do agente desnaturante. Não foram observadas diferenças de estabilidade estrutural nos processos de desnaturação das proteínas alternagina e bothropasina que pudessem ser relacionadas à formação do intermediário de $43 \mathrm{kDa}$ observado no processo de autólise. 


\section{Capitulo 6 - Referências}

ARAKI, S. et al. Involvement of specific integrins in apoptosis induced by vascular apoptosis-inducing protein 1. Toxicon, v.40, p.535-42, 2002.

ASSAKURA, M.T. et al. Molecular cloning and expression of structural domains of bothropasin, a P-III metalloproteinase from the venom of Bothrops jararaca. Toxicon, v.41, p.217-227, 2003.

AU, L.C. et al. A common precursor for a putative hemorrhagic protein and rhodostomin, a platelet aggregation inhibitor of the venom of Calloselasma rhodostoma: molecular cloning and sequence analysis. Biochem. Biophys. Res. Commun., v.181, p.585-593, 1991.

BEVIGLIA, L.; STEWART, G.J.; NIEWIAROWSKI, S. Effect of four disintegrins on the adhesive and metastatic properties of B16F10 melanoma cells in a murine model. Oncol. Res. , v.7, n.1, p. 7-20, 1995.

BJARNASON, J.B.; FOX, J.W. Hemorrhagic metalloproteinases from snake venoms. Pharmac. Ther. v.62, p.325-372, 1994.

BJARNASON, J.B.; FOX, J.W. Snake venom metalloendopeptidases: reprolysins. Methods Enzymol., v.248, p.345-368, 1995.

BLACK, R.A. et al. A metalloproteinase disintegrin that releases tumour-necrosis factoralpha from cells. Nature, v.385, p.729-733, 1997.

BLOBEL, C.P. Metalloprotease-disintegrins: links to cell adhesion and cleavage of TNF alpha and Notch. Cell, v.90, p.589-592, 1997.

BOTELHO, M.G. et al. Folding and stability of extracellular domain of the human amyloid precursor protein. J. Biol. Chem., v.278, n.36, p.34259-34267, 2003.

BRANDEN, C.; TOOZE, J. Introduction to protein structure. New York: Garland, 1999. 
BRADFORD, M.M. A rapid and sensitive method for the quantitation of microgram quantities of protein utilizing the principle of protein-dye binding. Analytical Biochemistry v.72, p.248-254, 1976.

BROOKS, P. C.; CLARK, R. A.; CHERESH, D. A. Requirement of vascular integrin alpha v beta 3 for angiogenesis. Science, v.264, p.569-571.1994.

BODE, W.; GOMIS-RUTH, F. X.; STOCKLER, W. Astacina, serralysins, snake venom and matrix metalloproteinases exhibit identical zinc-binding environments (HEXXHXXGXXH and Met-turn) and topologies and should be grouped into a common family, the 'metzincins'. FEBS Lett., v.331, p.134-140, 1993.

CALVETE, J.J. et al. The disulfide bond pattern of catrocollastatin C, a disintegrinlike/cysteine-rich protein isolated from Crotalus atrox venom. Protein Sci., v.9, n.7, p.1365$73,2000$.

CANTOR, C.R.; SCHIMMEL, P.R. Biophysical chemistry- part II. New York: W.H. Freeman and Company, 1980.

CANTOR, C.R.; TIMASHEFF, S.N. The proteins. New York: Academic Press. 1982. v.5, p.145-301.

CARDOSO, J.L.C. et al. Randomized comparative trial of three antivenoms in the treatment of envenoming by lance-headed vipers (Bothrops jararaca) in São Paulo, Brazil. Quat.J.Med., v.86, p.315-325, 1993.

CASTEL, S. et al. Alpha $\mathrm{v}$ integrin antagonists induce the disassembly of focal contacts in melanoma cells. Eur. J. Cell Biol., v.79, p.502-512, 2000.

CHIANG, H.S.; SWAIN, M.W.; HUANG, T.F. Characterization of platelet aggregation induced by human colon adenocarcinoma cells and its inhibition by snake venom peptides, trigramin and rhodostomin. Br. J. Haematol., v.87, p.325-331, 1994.

CHIANG, H.S.; YANG, R.S.; HUANG, T.F. The Arg-Gly-Asp containing peptide, rhodostomin, inhibits in vitro cell adhesion to extracellular matrices and platelet aggregation caused by saos-2 human osteosarcoma cells. Br. J. Cancer, v.71, n.2, p. 265-270, 1995.

CLARK, E. A.; HYNES, R.O. Ras activation is necessary for integrin-mediated activation of extracellular signal-regulated kinase 2 and cytosolic phospholipase A2 but not for cytoskeletal organization. J. Biol. Chem., v.271, p.14814-14818, 1996. 
COMINETTI, M.R. Estudos dos efeitos de metaloproteases/desintegrinas isoladas do veneno da serpente Bothrops alternatus sobre a adesão celular e a expressão gênica. 2004. 199f. Tese (Doutorado em Ciências Fisiológicas)- Departamento de Ciências Fisiológicas, Centro de Ciências Biológicas e Saúde, Universidade Federal de São Carlos. São Carlos-SP, 2004.

COMINETTI, M.R. et al. Alternagin-C, a disintegrin-like protein, induces vascular endothelial cell growth factor (VEGF) expression and endothelial cell proliferation in vitro. Journal of Biological Chemistry, v.279, p.18247-18255, 2004.

DANEN, E.H.J. et al. The disintegrin eristostatin interferes with integrin alpha 4 beta 1 function and with experimental metastasis of human melanoma cells. Exp. Cell Res., v.238, p.188-196, 1998.

DE LUCA, M. et al. Jararhagin and jaracetin: novel snake venom inhibitors of the integrin collagen receptor, alpha 2 beta 1. Biochim Biophys Res. Commun., v.206, p.570-576, 1995.

DENNIS, M.S. et al. Platelet glycoprotein Iia-IIb protein antagonists from snake venom: evidence for a family of platelet-aggregation inhibitors. Proc. Natl. Acad. Sci. USA, v.87, p. 2471-2475, 1989.

DOONAN, S. Protein purification protocols. London, UK: Humana Press, 1996.

DZAMBA, B.; BOLTON, M.; DESIMONE, D. Frontiers in molecular biology, cell adhesion. Oxford: Oxford University Press. cap. 4, p.100-154, 2001.

ESTEVÃO-COSTA, M. I. et al. Action of metalloproteinases mutalysin I and II on several components of the hemostatic and fibrinolytic systems. Thromb. Res., v.99, p.363-376, 2000.

EUGENIO, L.M. Expressão, purificação, caracterização e modelagem molecular da enzima phosphoglucose isomerase de Trypanossoma brucei. 2001. 126f. Dissertação (Mestrado)Instituto de Fisica de São Carlos, Universidade de São Paulo, São Carlos, 2001.

FASMAN, G. D. Circular dichroism and the conformational analysis of biomolecules. New york: Plenum, 1996.

FRIEDLANDER, M. et al. Definition of two angiogenic pathways by distinct alpha $\mathrm{v}$ integrins. Science, v.270, p.1500-1502, 1995. 
FRY, B.G. Structure-function properties of venom components from Australian elapids. Toxicon, v.37, p.11-32, 1999.

FUJIMURA, S. et al. Primary structure and autoproteolysis of brevilysin H6 from the venom of Gloydius halys brevicaudus. J.Biochem., v.128, n.2, p.167-73, 2000.

FUJIMURA, Y. et al. Purification and characterization of a non-haemorrhagic metalloproteinase from Agkistrodon halys brevicaudus venom. Thromb. Haemost., v.74, p.743-750, 1995.

GAY, C.C. et al. Proteolytic, edematogenic and myotoxic activities of a hemorrhagic metalloproteinase isolated from Bothrops alternatus venom. Toxicon, v.46, p.546-554, 2005.

GOULD, R.J. et al. Disintegrins: a family of integrin inhibitory proteins from viper venoms. Proc. Soc. Exp. Biol. Med., v.195, p.168-171, 1990.

GOMIS-RUTH, F.X.; KRESS, L.F.; BODE, W. First structure of a snake venom metalloproteinase: A prototypefor matrix metalloproteinases/collagenases. EMBO J., v.12, p.4151-4157, 1993.

GRAF, J. et al. Identification of an amino sequence in laminin mediating cell attachment, chemotaxis and receptor binding. Cell, v.48, p.989-996, 1987.

GRAMS, F. et al. Activation of snake venom metalloproteinases by a cysteine switch-like mechanism. FEBS Lett., v.335, p.76-80, 1993.

GUAN, A.L. et al. Purification and characterization of fibrinolytic enzyme from venom of the southern copperhead snake Agkistrodon contortrix contortrix. Arch. Biochem. Biophys., v.289, p.197-207, 1991.

GUTIERREZ, J.M. et al. Neutralization of local effects of Bothrops asper venom by polyvalent antivenin. Toxicon, v.19, p.493-500, 1981.

HENO, P. et al. Buerger's disease and coronary disease. Arch Mal Coeur Vaiss., v.93, n.10, p.1239-42, 2000.

HITE, L.A. et al. cDNA sequences for four snake venom metalloproteinase: structure, classification and their relation*ship to mammalian reproductive proteins. Arch. Biochem. Biophys., v.38, p.182-191, 1994. 
HOOPER, A. B.; ARCIERO, D.M. A di-heme cytochrome c peroxidase from Nitrosomonas europaea catalytically active in both the oxidized and half-reduced states. J.Biol.Chem. v.269, p.11878-11886, 1994.

HYNES, R. O. Integrins: a family of cell surface receptors. Cell, v.48, p.549-554, 1987.

HYNES, R.O. Integrins: versatility, modulation, and signaling in cell adhesion. Cell, v.110, p.673-687, 1992.

HUANG, T. F. et al. Trigramin. A low molecular weight peptide inhibiting fibrinogen interaction with platelet receptors expressed on glycoprotein IIb-IIIa complex. J. Biol. Chem. v.262, p.16157-16163, 1987.

IGARASHI, T. et al. Crystal structures of catrocollastatin/VAP2B reveal a dynamic, modular architecture of ADAM/adamalysin/reprolysin family proteins. FEBS Lett., v.581, n.13, p.2416-2422, 2007.

IVANA, J.; HENO, J. Adhesion receptors and cell invasion:mechanisms of an integrin-guided degradation of extracellular matrix. Cell Mol. Life Sci., v.57, p.16-24, 2000.

JOHNSON, E.K.; OWNBY, C.L. Isolation of a hemorrhagic toxin from the venom of Agkistrodon contortrix laticinctus (broad-banded copperhead) and pathogenesis of the hemorrhage induced by the toxin in mice. Int. J. Biochem., v.25, p.267-278, 1993.

JULIANO, R.L.; VARNER, J.A. Adhesion molecules in cancer: the role of integrins. Current Opinion in Cell Biology, v.5, p.812-818, 1993.

KAMIGUTI, A.S. et al. Systemic haemorrhage in rats induced by a haemorrhagic fraction from Bothrops jararaca venom. Toxicon, v.34, p.627-642, 1991.

KAMIGUTI, A.S. et al. Properties of fibrinogen cleaved by Jararhagin, a metalloproteinase from the venom of Bothrops jararaca. Thromb. Haemost., v.72, p.244-249, 1994.

KAMIGUTI, A.S. et al. Review article. Insights into the mechanism of haemorrhage caused by snake venom metalloproteinases. Toxicon, v.34, p.327-642, 1996. 
KINI, R.M.; EVANS, H.J. Inhibition of platelet aggregation by a fibrinogenase from Naja nigricollis venom independent of fibrinogen degradation. Biochim Biophys Acta, v.1095, p.117-121, 1991.

KLOCZEWIAK, M. et al. Platelet receptor recognition site on human fibrinogen. Synthesis and structure-function relationship of peptides corresponding to the carboxy-terminal segment of the gamma chain. Biochemistry, v.23, n.8, p.1767-74, 1984.

LAEMMLI, U.K. Cleavage of structural proteins during the assembly of the head of bacteriophage T4. Nature, v.227, p.680-685, 1970.

LAFLAMME, S.E.; AUER, K.L. Integrin signaling. Seminars in Cancer Biology, v.7, p.111$118,1996$.

LAKOWICZ, J.R. Principles of fluorescence spectroscopy, New York: Plenum Press, 1983.

LAKOWICZ, J.R. Introducion of fluorescence:------In Principles of Fluorescence Spectroscopy. 3.ed. New York: Springer Science, 2006. p.1-94.

LANÇAS, F.M. Cromatografia em fase gasosa, São Carlos: Acta, 1993.

LOMONTE, B. et al. Isolation of basic myotoxins from Bothrops moojeni and Bothrops atrox snake venoms. Toxicon, v.28, p.1137-1146, 1990.

LUNDSTRÖM, A. et al. The role of $\alpha 2 \beta 1$ and $\alpha 3 \beta 1$ integrin receptors in the initial anchoring of MDA-MB-231 human breast cancer cells to cortical bone matrix. Biochem. and Biophys. Res. Commun., v.250, p.735-740, 1998.

MANDELBAUN, F.R., REICHL, A.P., ASSAKURA, M.T. Isolation and characterization of a proteolytic enzyme from the venom of the snake Bothrops jararaca (Jararaca). Toxicon, v.20, p.955-972, 1982.

MINISTÉRIO DA SAÚDE. Manual de diagnóstico e tratamento de acidentes por animais peçonhentos. Brasília-DF: Editora da Fundação Nacional de Saúde, 2003.

MARIANO-OLIVEIRA, A. et al. Alternagin-C, a nonRGD-disintegrin, induces neutrophil migration via integrin signaling. European Journal of Biochemistry, v.270, p.4799-4808, 2003. 
MARKLAND, F.S. Snake venoms and the hemostatic system. Toxicon, v.36, p.1749-1800, 1998.

MARUYAMA, M. et al. Studies on blood coagulation and fibrinolysis in patients bitten by Bothrops jararaca (Jararaca). Thromb. Haemost., v.63, p.449-453, 1990.

MARSH, N. A. Snake venoms affecting the haemostatic mechanism - a consideration of their mechanisms, practical applications and biological significance. Blood Coagulation and Fibrinolysis, v.5, n.3, p.399-410, 1994.

MARUYAMA, K. et al. Isolation and amino acid sequence of flavostatin, a novel disintegrin from the venom of Trimeresurus flavoviridis. Peptides, v.18, p.73-78, 1997.

MORINI, M. et al. The $\alpha 3 \beta 1$ integrand is associated with mammary carcinoma cell metastasis, invasion and gelatinase B (MMP-9) activity. Int. J. Cancer, v.87, p.336-342, 2000.

MÉNEZ, A. Perspectives in molecular toxinology. Chichester, UK: Wiley, 2002.

MOURA-DA-SILVA, A.M. et al. Selective recognition of alpha2beta1 integrin by jararhagin, a Metalloproteinase/disintegrin from bBothrops jararaca venom. Thromb. Res. v.102, p.153$159,2001$.

MOURA-DA-SILVA, A.M. et al. Evidence for heterogeneous forms of the snake venom metalloproteinase jararhagin: a factor contributing to snake venom variability. Archives of Biochemistry and Biophysics, v.409, p.395-401, 2003.

MUNIZ, J.R. Estrutura tridimensional da Bothropasina, uma metaloprotease/desintegrina do veneno de Bothrops jararaca. 2007. 153f. Tese (Doutorado)- Instituto de Física de São Carlos, Universidade de São Paulo, São Carlos, 2007.

NAGASE, H.; WOESSNER, J.F. Matrix metalloproteinases. J. Biol. Chem., v.274, p.2149121494, 1999.

NELSON, D.L.; COX, M.M. Lehninger Principles of biochemistry. New York: Ed. Sarvier, 2007 
NIEWIAROWSKI, S. et al. Disintegrins and other naturally occurring antagonists of platelet fibrinogen receptors. Sem. Hematol., v.31, p.289-300, 1994.

OUYANG, C.; TENG, C. M.; HUANG, T. F. Characterization of snake venom components acting on blood coagulation and platelet function. Toxicon, v.30, p.945-966, 1992.

PAINE, M.J.I. et al. Purification, cloning, and molecular characterization of a high molecular weight hemorrhagic metalloprotease, jararhagin, from Bothrops jararaca venom. Insights into the disintegrin gene family.J.Biol. Chem., v.267, p.22869-22876, 1992.

PENTIKÄINEN, O. et al. RKKH peptides from the snake venom metalloproteinase of Bothrops jararaca bind near the metal ion-dependent adhesion site of the human integrin alpha2 I-domain. J. Biol. Chem. v. 274, n.44, p.31493-31505, 1999.

PETRUZZELLI, L.; TAKAMI, M.; HUMES, H.D. Structure and fuction of cell adhesion molecules. Am. J. Med., v.106, n.4, p.467-476, 1999.

QUEIROZ, L.S. et al. Pathological changes in muscle caused by haemorrhagic and proteolytic factors from Bothrops jararaca snake venom. Toxicon, v.23, n.2, p.341-5, 1985.

RAMOS, O.H.P. et al. Modulation of in vitro and in vivo angiogenesis by alternagin-C, a disintegrin-like protein from Bothrops alternatus snake venom and by a peptide derived from its sequence. Archives of Biochemistry and Biophysics, v.461, p.1-6, 2007.

RUOSLAHTI, E.; PIERSCHBACHER, M.D. New perspectives in cell adhesion: RGD and integrins. Science, v.238, n.4826, p.491-7, 1987.

SANCHEZ, E.F. et al. Biological activities of venoms from south american snakes.Toxicon, v.30, p.95-103, 1992.

SAUDEK, V.; ATKINSON, R.A.; PELTON, J.T. Three-dimensional structure of echistatin, the smallest active RGD protein. Biochemistry, v.30, n.30, p.7369-72, 1991. 
SELISTRE, H.S.; GIGLIO, J.R. Isolation and characterization of a thrombin-like enzyme from the venom of the snake Bothrops insularis (jararaca ilhoa). Toxicon, v.25, p. 1135-1144, 1987.

SELISTRE, H.S. et al. Isolation and characterization of hemorrhagic, myonecrotic and edema-inducing toxins from Bothrops insularis (Jararaca Ilhoa) snake venom. Toxicon, v.28, p.261-273,1990.

SERRANO,S.M.T. et al. Purification, characterization and amino acid sequence of a serine proteinase, PA-BJ, with platelet aggregation activity from the venom of Bothrops jararaca. Biochemistry, v.34, p.7186-7193, 1995.

SILVA, M.B. et al. A prothrombin activator from Bothrops erythromelas (jararaca-da-seca) snake venom: characterization and molecular cloning. Biochem. J., v.369, p.129-139, 2003.

SILVERSTEIN, R.M.; BASSLER, G.C.; MORRILL, T.C. Identificação espectrométrica de compostos orgânicos. Rio de Janeiro: Ed. Guanabara Dois S.A., 1979.

SHEU, J.R., LIN, C.H., HUANG, T.F. Triflavin, an antiplatelet peptide, inhibits tumor cellextracellular matrix adhesion through an arginine-glycine-aspartic acid-dependentn mechanism. J. Lab.Cin.Med. v.123, n.2, p.256-263, 1994.

SHEU, J.R.; HUANG, T.F. Ex-vivo and in-vivo antithrombotic effect of triflavin, an RGDcontaining peptide. J. Pharm. Pharmacol, v.46, n.1, p.58-62, 1994.

SHEU, J.R. et al. Triflavin, an Arg-Gly-Asp-containing peptide, prevents platelet plug formation in in vivo experiments.Eur. J. Pharmacol., v.294, p.231-238, 1995.

SHEU, J. R. et al. Inhibition of angiogenesis in vitro and in vivo: comparison of the relative activities of triflavin, an Arg-Gly-Asp-containing peptide and anti-alpha(v)beta3 integrin monoclonal antibody. Biochim. Biophys. Acta, v.1336, p.445-454, 1997.

SHIMOKAWA, K. et al. Expression, activation and processing of the recombinant snake venom metalloproteinase, Pro-Atrolysin E. Arch. Biochem. Biophys., v.335, p.283-294, 1996.

SOUZA, D.H.F. et al. The disintegrin-like domain of the snake venom metalloprotease alternagin inhibits alpha2betal integrin-mediated cell adhesion. Arch. Biochem. Biophys., v.384, p.341-350, 2000. 
STONE, A.L.; KROEGER, M.; SANG, Q.X. Structure-function analysis of the ADAM family of disintegrin-like and metalloproteinase-containing proteins (review). J.Protein Chem., v.18, n.4, p.447-65, 1999.

STRYER, L. Bioquímica. Rio de Janeiro-RJ: Ed.Guanabara Koogan S.A., 1996.

TAKEDA, S. et al. Crystal structures of VAP1 reveal ADAMs' MDC domain architecture and its unique C-shaped scaffold. EMBO J., v.25, n.11, p.2388-2396, 2006.

TAKEYA, H. et al. Primary structures of platelet aggregation inhibitors (disintegrins) autoproteolytically released from snake venom hemorrhagic metalloproteinases and new fluorogenic peptide substrates for these enzymes. J. Biochem., v.113, p.473-483, 1993.

TASHIRO, K. et al. A synthetic peptide containing the IKVAV sequence from the chain of laminin mediates cell attachment, migration and the neurite outgrowth. J.Biol.Chem., v.264, p.16174-16182, 1989.

TRIKHA, M.; DE CLERCK, Y. A.; MARKLAND, F. S. Contortrostatin, a snake venom disintegrin, inhibits beta 1 integrin-mediated human metastatic melanoma cell adhesion and blocks experimental metastasis.Cancer Res., v.54, p.4993-4998, 1994.

YAMADA, D.; SHIN, Y.; MORITA, T. Nucleotide sequence of a cDNA encoding a common precursor of disintegrin flavostatin and hemorrhagic factor HR2a from the venom of Trimeresurus flavoviridis. FEBS Lett., v.451, p.299-302, 1999.

YEH, C.H.; PENG, H.C.; HUANG, T.F. Accutin, a new disintegrin, inhibits angiogenesis in vitro and in vivo by acting as integrin alphavbeta3 antagonist and inducing apoptosis. Blood, v.92, p.3268-3276, 1998.

USAMI, Y. et al. A 28 kDa-protein with disintegrin-like structure (jararhagin-C) purified from Bothrops jararaca venom inhibits collagen- and ADP-induced platelet aggregation. Biochem. Biophys. Res. Commun., v.201, p.331-339, 1994.

WERR, J., et al. Integrin $\alpha 2 \beta 1(\mathrm{VLA}-2)$ is principal receptor used by neutrophils for locomotion in extravascular tissue. Blood. v.95, p.1804-1809, 2000.

WOLPERT, L. Princípios de biologia de desenvolvimento. Porto Alegre: Artes Médicas Sul, 2000. p. 10-15. 
ZHOU, O.; SMITH, J.B.; GROSSMAN, M.H. Molecular cloning and expression of catrocollastatin, a snake-venom protein from Crotalus atrox (western diamondback rattlesnake) which inhibits platelet adhesion to collagen. Biochem., v.307, p.411-417, 1995. 